International Journal of Education and Science

print ISSN: 2618-0553; online ISSN: 2618-0561; DOI: 10.26697/ijes Journal Website: https://ijes.world

SOCIAL AND BEHAVIORAL SCIENCES

Law

Article History

Received: 10.04.2021

Accepted: 10.06 .2021

Published: 25.12.2021

\author{
${ }^{1}$ Simcord Information Services SIA, Latvia \\ ${ }^{2}$ Simcord LLC. Technologies, Ukraine \\ ${ }^{3}$ Simon Kuznets Kharkiv National University of Economics, Ukraine \\ ${ }^{4}$ Research Center of Economic and Legal Solutions in the Area of Application \\ of Distributed Ledger Technologies, Ukraine \\ * Corresponding Author's Email: Alexander.Kud@simcord.com
}

\title{
Комплексна класифікація віртуальних активів
}

Кудь А. А. ${ }^{1,2,3,4}$

${ }^{1}$ Сімкорд Інформейшнс Сервісіз, Латвія

${ }^{2}$ ТОВ “Сімкорд”. Технології, Україна

${ }^{3}$ Харківський національний економічний університет імені Семена Кузнеия, Украӥна

${ }^{4}$ Науково-дослідний центр економіко-правових рішень у сфері застосування технологій розподіленого реєстру, Україна

\section{Комплексная классификация виртуальных активов}

Кудь А. А. ${ }^{1,2,3,4}$

${ }^{1}$ Симкорд Информейшнс Сервисиз, Латвия

2 ООО “Симкорд”. Технологии, Украина

${ }^{3}$ Харьковский национальный экономический университет имени Семена Кузнеияа, Украина

${ }^{4}$ Научно-исследовательский центр экономико-правовых решений в сфере применения технологий распределенного реестра, Украина

\begin{abstract}
Background: One of the problems of the modern lawmakers in different countries is that they try to regulate an object before they study the nature of its origin, which, logically, entails many errors regarding its definition in the legal framework. The absence of unified definitions and clear classification of virtual assets as tools for implementing the methods of financial and management accounting of property according to their fundamental and unique features makes it nearly impossible to determine the features of virtual assets important for legal regulation and, therefore, to enshrine them in laws and establish a proper legal framework. The paper is dedicated to solving a relevant and crossdiscipline scientific and applied task of developing a comprehensive multilevel classification of virtual assets. Unlike the few existing classifications that focus on parts of the virtual asset phenomenon and selective methods of its implementation, the paper proposes an all-encompassing comparison of all known types of virtual assets, which confirms the comprehensiveness of the classification proposed in this paper.

Purpose: To develop and substantiate a comprehensive and multilevel classification of known types of virtual assets, which allows solving the cross-discipline scientific and applied task of systematizing virtual assets for future development of a single approach to regulating relations, the objects of which are different types of virtual assets.

Materials and Methods: In order to study the nature of virtual assets and develop a comprehensive classification, a set of scientific research methods has been used: analysis, including cause and effect analysis, synthesis, comparison, generalization, systematization and interpretation of results and induction.

Results: The author describes a triune nature of virtual assets: technological, economic and legal, information and applied. This classification of virtual assets will allow determining promising tools for accounting of property and rights. Unlike other known approaches to differentiating virtual assets, where crypto-assets (or cryptocurrencies) were unjustified "leaders", the author has distinguished the group of tokenized assets for the first time. This particular group, due to its direct relation to property, allows performing accounting as well as reaccounting of property and rights in modern digital accounting systems - decentralized information platforms based on the distributed ledger technology (blockchain), whereas this accounting cannot be performed using crypto-assets due to absence of direct relation to property. Out of virtual assets, the author distinguishes a digital asset and analyzes the semantic features of the term "digital asset". The digital asset is based on a unique information resource as the original asset and on the property of derivativeness from the real asset, which greatly differentiates it from other types of virtual assets. All of
\end{abstract}


that allows considering it as an effective tool for implementing the methods of financial and management accounting of property. Thus, owners of digital assets can use the new way of accounting of their property and personal non-property rights. Based on the properties of a digital asset, the author distinguishes other types of virtual assets: polyasset and monoasset, with the relevant examples. The author provides the characteristics of their features and structural components while comparing them to the features of digital assets and giving clear and well-known financial and legal analogies regarding the implementation of mutual obligations between parties to a traditional deal. The paper also contains the first systematization of seven properties and parameters of a tokenized asset and, therefore, description of properties of three variations of a tokenized asset: monoasset, polyasset and digital asset. This allowed presenting the varieties of virtual assets as a three-level classification based on the complexity of the nature of virtual assets. The author's classification distinguishes seven types of virtual assets and contains their description.

Conclusions: Overall, the proposed approach to classification allows giving a scientific answer to the question of how to compare the multitude of known virtual assets and how to relate them to the legal framework of a state. These developments will be useful for legislators in basically every country, financial, tax and banking state bodies, as well as private companies when keeping books and performing accounting of virtual assets in their business activity.

Keywords: distributed ledger, blockchain, virtual asset, tokenized asset, digital asset, polyasset, monoasset, cryptoasset, decentralized information platform.

DOI: https://doi.org/10.26697/ijes.2021.3.6 JEL: K10, K24, M15, O38 UDC: $340: 330$

Cite this article as: Kud, A. A. (2021). Kompleksnaja klassifikacija virtualnyh aktivov [Comprehensive classification of virtual assets]. International Journal of Education and Science, 4(3-4), 64-91. https://doi.org/10.26697/ijes.2021.3.6 [in Russian]

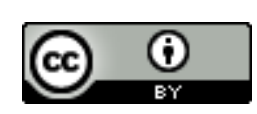

(C) 2021 Kud A. A.

Published by Archives of International Journal of Education and Science

Open Access under a Creative Commons "Attribution" 4.0 Worldwide

\section{Введение}

Отсутствие единого подхода к регулированию общественных отношений, объектами которых являются токены распределенного реестра, детерминировано непониманием со стороны государств и международных организаций механизмов для практического применения токенов распределенного реестра, в частности виртуальных активов как инструментов для реализации способов финансового и управленческого учета имущества. На сегодняшний день существуют разные позиции национальных регуляторов в отношении классификации токенов распределенного реестра. Один из наиболее известных подходов содержится в Методологических рекомендациях для составления запросов в отношении нормативноправовой базы первичного размещения монет (ICO), разработанных Swiss Financial Market Supervisory Authority (далее - FINMA). Швейцарским регулятором в качестве основного критерия для классификации токенов была взята его экономическая функция. Так, FINMA различает три вида токенов распределенного реестра:

- платежные токены (payment tokens), предназначенные либо для использования в настоящем или будущем в качестве средства оплаты товаров или услуг, либо в качестве средства перевода денег или какой-либо стоимости;

- сервисные токены (utility tokens), предназначенные для обеспечения цифрового доступа к приложению или услуге с помощью инфраструктуры на основе распределенного реестра;

- токены активов (asset tokens), которые представляют собой активы, такие как долговые обязательства или требования по акциям эмитента. Под токенами активов подразумеваются, например, обещание доли в будущих доходах компании или будущих потоках капитала (Kud, Kucheriavenko, \& Smychok, 2019; Swiss Financial Market Supervisory Authority, 2018).

Британская целевая группа по криптоактивам выделяет токены обмена (exchange tokens), токены - ценные бумаги (security tokens) и сервисные токены (utility tokens) (Braddick, Bailey, \& Ramsden, 2018). В свою очередь, Управление по финансовому регулированию и надзору Великобритании наряду с этими тремя видами говорит также о токенах - электронных деньгах (еmoney tokens) (Financial Conduct Authority, 2019).

4 июля 2018 года Парламентом Республики Мальта был принят Virtual Financial Assets Act, в соответствии с которым было введено понятие DLT-актива (Distributed Ledger Technology), который может быть следующих видов:

- виртуальный токен (virtual token) - запись в цифровой среде, которая не представляет ценности и не используется за пределами платформы, функционирующей посредством применения технологии распределенного реестра, в рамках которой осуществляется выпуск токенов, которые эмитент DLT-актива может обменять на денежные средства исключительно в пределах данной платформы. В эту категорию не входят электронные деньги;

- виртуальный финансовый актив (virtual financial asset) означает любую запись в цифровой среде, которая используется в качестве цифрового средства обмена, расчетной единицы или меры стоимости и не представляет собой электронные деньги, финансовый инструмент или виртуальный токен;

- электронные деньги (electronic money), в которых обязательным является наличие денежного 
требования к эмитенту в связи с передачей ему денежных средств;

- финансовый инструмент (financial instrument) включает помимо деривативов любые ценные бумаги, которые могут обращаться на рынке капиталов (акции, облигации), инструменты валютного рынка, паи инвестиционных фондов и иные финансовые продукты (Kud, Kucheriavenko, \& Smychok, 2019; Parliament of Malta, 2018).

Важно отметить, что для использования в экономике и, как результат, для установления корректного правового режима существенный интерес представляют более комплексные по своей природе объекты, которые в том числе могут быть созданными на основе токенов распределенного реестра, - виртуальные активы.

В октябре 2018 года Группа разработки финансовых мер борьбы с отмыванием денег (Financial Action Task Force, далее - FATF) внедрила изменения в свои Рекомендации и дополнила их такими определениями, как «виртуальный актив» и «поставщик услуг по виртуальным активам» (Financial Action Task Force, 2012). FATF определяет виртуальный актив как «цифровое выражение ценности, которым можно торговать в цифровом формате или которое можно переводить и использовать для платежных или инвестиционных целей». Также отмечается, что виртуальные активы не включают в себя цифровые представления фиатных валют, ценных бумаг и других финансовых активов, которые уже охвачены в других разделах Рекомендаций FATF (Financial Action Task Force, 2020).

Исходя из определения «виртуальный актив», предложенного FATF, можно выделить такие ключевые признаки виртуального актива:

- представляет собой цифровое выражение ценности;

- им можно торговать в цифровом формате или переводить;

- может использоваться для платежных или инвестиционных целей.

Как видно из определения «виртуальный актив», его дефиниция сформирована всеобъемлющим образом и может охватывать виртуальные активы, реализованные не только на базе технологии распределенного реестра, но и созданные на базе других технологий (например: бездокументарные ценные бумаги, электронные деньги). И это значительно усложняет задачу определения правового режима данного объекта. Поскольку Рекомендации FATF являются общепризнанным международным стандартом по противодействию отмыванию денег и финансированию терроризма, то внимание финансистов и регуляторов по всему миру далее сфокусировалось на термине «виртуальный актив».

На целесообразность определения виртуального актива при создании соответствующей регуляторной базы обращается внимание в Проекте Постановления Европейского парламента и Совета «О рынках криптоактивов и внесении изменений в
Директиву (EC) 2019/1937» (European Commission, 2020), включая необходимость основываться на Рекомендациях FATF. Кроме того, Рекомендации FATF в отношении вопроса регулирования виртуальных активов были имплементированы в нормы национального законодательства многих государств и их зависимых территорий, среди которых: Гонконг (Securities and Futures Commission, 2019; Hong Kong's Securities and Futures Commission, 2019), Украина (Verkhovna Rada of Ukraine, 2019), Пакистан (Financial Monitoring Unit Government of Pakistan, 2020), Виргинские Острова (British Virgin Islands Financial Services Commission, 2020), Острова Кайман (Stuarts Walker Hersant Humphries, 2020) и др. Также в своей работе подходом FATF в отношении виртуальных активов руководствуется Всемирная федерация бирж (World Federation of Exchanges, 2019).

По своей сути виртуальные активы могут обладать свойством производности от имущества или от имущественных прав. Поэтому именно классификация виртуальных активов, в том числе таких, которые созданы на основе токенов распределенного реестра, позволит создать научное обоснование для правовой регламентации применения в разных секторах экономики принципиально новых инструментов для реализации способов финансового и управленческого учета имущества.

Важно также отметить, что одной из проблем современных законодателей в разных странах является то, что они пытаются регулировать объект, не разобравшись в природе его происхождения, что, логически, влечет и множество ошибок относительно его определения в правовом поле (Kud, 2020a). Таким образом, вопрос корректного правового регулирования и, в частности, научно обоснованного определения основных характеристик объекта регулирования виртуальных активов - с каждым днем обретает все большую актуальность Только научно обоснованная классификация виртуальных активов как инструментов для реализации способов финансового и управленческого учета имущества позволит избежать ситуации, при которой по своей сути разные объекты будут регулироваться законодательством, создающим единый правовой режим для них. Иными словами, отсутствие унифицированных определений и четкой классификации виртуальных активов как инструментов для реализации способов финансового и управленческого учета имущества по их фундаментальным, отличительным признакам делает практически невозможным определение важных для правового регулирования характеристик виртуальных активов, а следовательно, и их закрепление в нормах права и установление надлежащего правового режима. Установлению правового режима видов виртуальных активов, на наш взгляд, способствует выявление видовых свойств, позволяющих их 
классифицировать и определить сферы и субъектов регулирования отношений, возникающих в связи с применением тех или иных видов виртуальных активов как инструментов для реализации способов финансового и управленческого учета имущества. Анализ изучения проблемы позволяет выявить установление правового режима объекта, ранее неизвестного системе права, и является очень важным для дальнейшего практического применения его свойств в экономике и праве (Kud, 2020a).

\section{Материалы и Методы \\ С целью написания работы, посвященной вопросу изучения механизмов возможного использования виртуальных активов в разных секторах экономики вследстве обоснованной классификации виртуальных активов как инструментов для реализации способов финансового и управленческого учета имущества, использовались следующие методы научного исследования: анализ, в том числе анализ причинно-следственных связей, синтез, сравнительный метод, метод обобщения, систематизации и интерпретации результатов и индукция.}

\section{Результаты и Обсуждение}

Стоит отметить, что классификация является общенаучным методом познания и представляет собой упорядочивание информации в процессе изучения новых объектов (Kalambet, Ivanov, \& Pivniak, 2015). Классификация объектов предусматривает выделение совокупностей объектов, в каждой из которых общий для всех признак проявляется особым образом (Chmylenko \& Zhuk, 2014).

Одним из самых важных и часто нарушаемых правил для корректной классификации является то, что каждая классификация может проводиться только по одному основанию. Основание классификации - это признак, который дает возможность разделить объем родового понятия (всю совокупность классифицируемых по данной классификации объектов) на виды (видовые понятия - члены, части этой совокупности) (А. Novikov \& Novikov, 2010). Для фундаментального изучения того или иного феномена необходимым является рассмотрение его природы, под которой традиционно подразумевается сущность, основное свойство чего-либо (Kuznetsov, 1998).

\section{Природа виртуальных активов}

На наш взгляд, для построения классификации виртуальных активов как инструментов для реализации способов финансового и управленческого учета имущества, предоставляющей объективную картину в отношении классифицируемого объекта, необходимо отталкиваться от комплексности природы виртуальных активов, которая, в свою очередь, имеет составляющие - технологическую, экономико-правовую и информационноприкладную природу. Так, основанием классификации виртуальных активов как инструментов для реализации способов финансового и управленческого учета имущества будет комплексность их природы.

Технологическая природа виртуальных активов. Одним из важных свойств виртуальных активов следует считать технологический аспект их реализации, который указывает на создание виртуального актива в системе на базе определенной технологии. Технологическую природу виртуальных активов необходимо рассматривать с позиции дифференциации технологии, на базе которой создается виртуальный актив, на технологию распределенного реестра и иные технологии.

Говоря о технологии распределенного реестра, вначале необходимо рассмотреть соотношение категорий «распределенный реестр» и «блокчейн». Блокчейн является одним из видов распределенного реестра, в котором для достижения консенсуса (согласия) между сетевыми узлами используется последовательность блоков (от англ. block chain или blockchain - цепочка блоков). Блоки организованы в хронологической последовательности, соединены друг с другом и защищены криптографическими методами. Каждый такой блок содержит хеш-код (число фиксированной длины, которое ставится в соответствие данным произвольной длины таким образом, чтобы вероятность появления различных данных с одинаковым хешем стремилась к нулю, а восстановить данные по их хешу было как можно труднее), вычисленный из предыдущего блока, и полезную нагрузку. В качестве полезной нагрузки может выступать информация о транзакциях, сделках, заключенных договорах, внесении в реестр данных о физическом лице, субъекте предпринимательской деятельности, имуществе и т. д. Другими словами, полезной нагрузкой может выступать практически любая информация. По своей сути блокчейн является постоянно пополняющимся реестром записей, в который можно только добавлять данные, но при этом невозможно удалять или изменять данные, сохраненные в предыдущих блоках (Kud, Kucheriavenko, \& Smychok, 2019).

Важно отметить, что блокчейн по своей сути является одним из видов реализации технологии распределенного реестра, в основе которого лежит токен распределенного реестра как объект учета.

Технология распределенного реестра является многофункциональной и многоуровневой информационной технологией, которая предназначена для надежного хранения, учета и передачи различной информации (Kud, Kucheriavenko, \& Smychok, 2019).

Распределенный реестр - это набор технических и программных устройств, работающих совместно, но децентрализованно и независимо друг от друга с целью регистрации событий с данными токена распределенного реестра посредством транзакций токена распределенного рееста, 
синхронизированных с помощью определенного алгоритма консенсуса. Иными словами, распределенный реестр представляет собой базу данных, которая распределена между несколькими сетевыми узлами (нодами), каждый из которых получает данные из других узлов и хранит полную копию реестра. При этом такие узлы обновляются независимо друг от друга. Ключевой особенностью распределенного рееста является децентрализация, то есть отсутствие единого центра хранения и регистрации данных. При этом информация во всех узлах распределенного реестра должна быть валидна и актуальна, что возможно только посредством достижения согласия между всеми узлами такого реестра. Каждый узел составляет и записывает обновления реестра независимо от других узлов. Затем узлы голосуют за обновления, чтобы удостовериться, что большинство узлов согласно с окончательным вариантом. Достижение согласия в отношении одной из копий реестра называется консенсусом, этот процесс выполняется автоматически с помощью алгоритма консенсуса. Как только консенсус достигнут, распределенный реестр обновляется, и последняя согласованная версия реестра сохраняется в каждом узле (Kud, Kucheriavenko, \& Smychok, 2019).

Распределенный реестр является технологическим решением в цифровом пространстве, которое обеспечивает современный способ учета токенов распределенного реестра. По сути, распределенный реестр является системой учета, в основе которой находятся объекты учета в виде токенов распределенного реестра - объектов системы учета токенов распределенного реестра, являющихся идентификаторами структурированной определенным образом информации, которая может быть, но не исключительно, производной от исходного актива. Иными словами, технология распределенного реестра является основой для создания систем учета токенов распределенного реестра, которые расширяют возможности использования виртуальных активов и их интеграции в разные сферы. По своей технологической природе виртуальные активы, которые создаются в системах учета токенов распределенного реестра, являются токенами распределенного реестра.

Система учета токенов распределенного реестра представляет собой информационную систему регистрации, хранения, обмена данными токенов распределенного реестра, которая основана на технологии распределенного реестра (Kud, 2020a). Стоит отметить, что токен распределенного реестра является основным инструментом распределенного реестра (Kud, 2020a). То есть определение распределенного реестра в качестве системы учета токенов распределенного реестра позволяет рассматривать токен распределенного реестра как объект, учет которого ведется в такой системе.

Как было отмечено выше, токен распределенного реестра - это основной инструмент распределенного реестра. По своей технологической природе виртуальные активы, которые создаются в системах учета токенов распределенного реестра, являются токенами распределенного реестра. Важно также отметить, что рассмотрение токена распределенного реестра и его единиц учета в рамках технологической природы позволяет говорить о категории «данные токена распределенного реестра», которые являются совокупностью атрибутов и свойств токена распределенного реестра:

- хеш токена распределенного реестра;

- хеши транзакций;

- количество единиц учета токена распределенного реестра;

- адрес хранения единиц учета такого токена распределенного реестра, а также других атрибутов и свойств, которые могут быть определены создателем такого токена распределенного реестра. Стоит отметить, что атрибуты токена распределенного реестра представляют собой необходимые, постоянные его признаки (Ozhegov \& Shvedova, 2010), тогда как свойства токена распределенного реестра - это признаки, составляющие его отличительную особенность (Ozhegov \& Shvedova, 2010), но при этом не являющиеся обязательными.

Токен распределенного реестра является записью в системе учета токенов распределенного реестра. Осуществление любой транзакции токена распределенного реестра сопровождается формированием идентификатора - ID транзакции (выход односторонней хеш-функции), представляющего собой вид идентификатора, присваиваемый транзакции токена распределенного реестра и формируемый на основе данных токена распределенного реестра. Идентификатор генерируется на основании данных транзакции индивидуально для каждой транзакции и является единственным в своем роде. При этом такой идентификатор является общедоступным. ID транзакции является однозначно связанным с немодифицируемым, валидным и сохраненным в распределенном реестре описанием данной транзакции, которое включает дату, идентификацию адресов учета токена распределенного реестра и его объем при осуществлении транзакции. Уникальный идентификатор применяется в информационных системах и может быть использован для идентификации определенного объекта в сети (Kud, Kucheriavenko, \& Smychok, 2019). Таким образом, фаза создания токена распределенного реестра начинается в момент поступления запроса в распределенный реестр на осуществление транзакции определенного количества единиц учета такого токена распределенного реестра (Kud, Kucheriavenko, \& Smychok, 2019). Под обращением токена распределенного реестра следует понимать передачу определенного количества единиц учета такого токена распределенного реестра от одного пользователя системы учета токенов 
распределенного реестра к другому. Иначе говоря, токен распределенного реестра - это его единицы учета, обращающиеся в распределенном реестре посредством транзакции с уникальным идентификатором (Kud, 2019a). Это означает, что токен распределенного реестра необходимо исследовать как объект, учет которого осуществляется посредством системы учета токенов распределенного реестра, а его единицы учета - как единицы учета виртуального актива распределенного реестра в целом.

Можно говорить о ряде признаков, позволяющих рассматривать токен распределенного реестра (его единицы учета) в качестве объекта (Рисунок 1):

\section{Рисунок 1}

Система учета токенов распределенного реестра

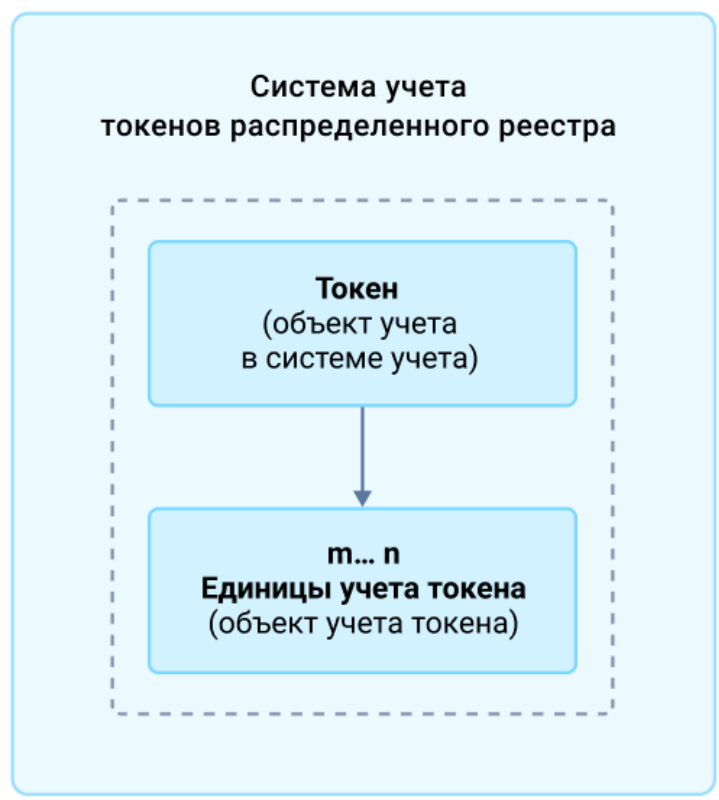

Примечание: m - минимальное неделимое и/или делимое числовое значение единиц учета токена распределенного реестра.

- пользователи системы учета (распределенного реестра) могут самостоятельно создавать токены распределенного реестра;

- токен распределенного реестра существует в виде идентификатора и имеет собственные единицы учета в системе учета;

- пользователь системы учета, исходя из своих целей, в момент создания токена распределенного реестра может самостоятельно указывать выпускаемое количество единиц учета такого токена распределенного реестра;

- между пользователями системы учета передается не сам токен распределенного реестра, а его единицы учета;

- пользователи распределенного реестра как среды обращения токена распределенного реестра ведут учет коллективно, как следствие - не возникает возможности единолично и бесследно изменять или удалять данные токена распределенного реестра (Kud, 2020a).
Таким образом, токен распределенного реестра имеет единицы учета в системе учета токенов распределенного реестра, и пользователь такой системы учета, исходя из своих целей, в момент создания токена распределенного реестра может самостоятельно указывать выпускаемое количество единиц учета такого токена распределенного реестра. В свою очередь, токен распределенного реестра как объект учета может быть самостоятельным объектом имущественных отношений, имеющим собственные единицы учета в системе учета токенов распределенного реестра. Одной из особенностей токена распределенного реестра является его двойственность, то есть:

- токен распределенного реестра может являться объектом, посредством которого осуществляется учет любого имущества, существующего вне системы учета токенов распределенного реестра;

- единица учета такого токена распределенного реестра может выступать единицей измерения объема прав по отношению к имуществу, учитываемому посредством токена распределенного реестра.

Поэтому объектом учета в системе учета токенов распределенного реестра может быть любое имущество. При этом важно отметить, что между пользователями такой системы учета токенов распределенного реестра передается не сам токен распределенного реестра, а его единицы учета.

Иначе говоря, единицы учета токенов распределенного реестра, обращающиеся в системах учета токенов распределенного реестра, это и есть виртуальные активы (далее виртуальные активы распределенного реестра), которые в системах учета токенов распределенного реестра представлены в виде токенов распределенного реестра с уникальными идентификаторами. Уникальный идентификатор применяется в информационных системах и предназначен для идентификации определенного объекта в сети, а также позволяет исключить любую вероятность дублирования этого объекта и подтверждает его подлинность (Kud, 2019b). Таким образом, идентификатор является атрибутивным признаком объекта учета, служащим для его идентификации, который выражен в виде уникального набора буквенных и/или цифровых символов определенной длины и присваивается объекту учета в среде его обращения. То есть технически виртуальные активы распределенного реестра являются токенами распределенного реестра.

Основой для создания виртуальных активов также могут служить иные технологии, отличные от технологии распределенного реестра, позволяющие на своей базе реализовывать те или иные системы учета. В качестве примеров виртуальных активов, созданных в системах учета на базе иных технологий, отличных от технологии распределенного реестра (далее - виртуальные активы нераспределенного реестра), можно привести: монеты в компьютерных играх, 
электронные деньги, бездокументарные ценные бумаги, цифровые абонементы, цифровые подарочные сертификаты и пр. Кроме того, природа виртуальных активов нераспределенного реестра является достаточно изученной, в силу чего дальнейшая их классификация не представляет интереса в рамках данного исследования.

Экономико-правовая природа виртуальных активов распределенного реестра. Выйти на уровень классификации, который следует за уровнем, основывающимся на рассмотрении технологической природы, позволяет экономическая природа виртуального актива распределенного реестра как одна из составляющих экономико-правовой природы виртуального актива распределенного реестра.

Как было указано ранее, основное функциональноцелевое назначение технологии распределенного реестра сводится к возможности создания на его основе современных систем учета информации нового поколения. Таким образом, в рамках анализа экономической составляющей экономикоправовой природы виртуального актива распределенного реестра необходимо рассматривать виртуальный актив распределенного реестра с позиции его соответствия инструменту, с помощью которого в системе учета токенов распределенного реестра осуществляется учет информации об имуществе.

Как сказано выше, технически виртуальные активы распределенного реестра являются токенами распределенного реестра. Единицы учета токена распределенного реестра могут выступать единицами измерения объема прав по отношению к такому токену распределенного реестра, в то время как токен распределенного реестра может являться объектом учета любого имущества, существующего вне системы учета (за рамками распределенного реестра):

- объектов гражданских прав (денег, ценных бумаг, результатов работ, услуг, результатов интеллектуальной деятельности, информации, а также других материальных и нематериальных благ);

- активов как разновидности имущества, представляющего собой ресурс, который контролируется предприятием в результате прошлых событий и от которого предприятие ожидает получить будущие экономические выгоды (Ministry of Finance of the Russian Federation, 1999);

- имущественных прав (права пользования, права распоряжения и права владения объектом гражданских прав).

Описанная двойственность природы токена распределенного реестра объясняется тем, что токен распределенного реестра существует в системе учета токенов распределенного рееста в виде идентификатора и также имеет собственные единицы учета (Kud, 2020a). Таким образом, посредством виртуального актива распределенного реестра может осуществляться учет имущества, которое может выступать самостоятельным объектом правоотношений.

Говоря о целевом назначении учета, осуществляемого посредством виртуальных активов распределенного реестра в системе учета токенов распределенного реестра, важно отметить, что он может быть определен как один из нижеприведенных:

Финансовый учет. Осуществление финансового учета с помощью системы учета токенов распределенного реестра посредством виртуального актива распределенного реестра возможно благодаря тому, что:

- виртуальный актив распределенного реестра может быть представлен как инвентарный номер, присваиваемый имуществу для осуществления его учета посредством системы учета токенов распределенного реестра;

- записи о единицах учета виртуального актива распределенного реестра определяются как товар, существующий в рамках гражданского оборота, и могут коррелировать с единицами финансового учета имущества.

«Гражданский (имущественный) оборот представляет собой совокупность сделок всех его участников и возникающих на этой основе их обязательственных отношений, юридически оформляющих экономические отношения товарообмена» (Vitryanskii et al., 2010). Иными словами, термин «гражданский оборот» призван прежде всего обозначать сам процесс перехода объектов гражданских прав от одного лица к другому (Zakharkina, 2017). Гражданский оборот имеет имущественный, товарный характер (Em, 2006). Таким образом, предельно однозначным для понимания освещаемого вопроса будет рассмотрение виртуального актива распределенного реестра в качестве товара.

Товар представляет собой специфическое экономическое благо, произведенное для обмена. К. Менгер утверждал, что экономическое благо становится товаром, независимо от его способности к передвижению, независимо от лиц, предлагающих его для продажи, от его материальности, от характера его как продукта труда, но обязательно предназначено для обмена. Способность товара удовлетворять ту или иную потребность человека составляет его потребительную стоимость (ею обладает любой товар). В то время как способность товара к обмену в определенных количественных пропорциях есть меновая стоимость (Vidyapin et al., 2003).

Таким образом, для определения виртуального актива распределенного реестра в качестве товара необходимым является соблюдение следующих условий:

1. В основе такого виртуального актива распределенного реестра должна быть сделка с имуществом.

Находящийся в гражданском обороте виртуальный актив распределенного реестра как инструмент для реализации способа финансового учета имущества 
может быть создан исключительно в процессе подготовки и заключения договора, в котором будет описано право пользования имуществом или право распоряжения имуществом.

2. Стороны сделки, объектом которой выступает виртуальный актив распределенного реестра, должны быть идентифицированы.

Данное требование обуславливает необходимые функциональные аспекты работы системы учета токенов распределенного реестра и состоит в необходимости обеспечения идентификации пользователя, который осуществил перевод единиц учета виртуального актива распределенного реестра, и пользователя, которому были переданы эти единицы учета виртуального актива распределенного реестра в рамках определенной сделки.

3. Существует возможность подтверждения сведений об имуществе, сделка с которым может лежать в основе виртуального актива распределенного реестра, а также о создании виртуального актива распределенного реестра.

Для обеспечения соблюдения ряда правовых гарантий в отношении виртуального актива распределенного реестра обязательным является наличие документально подтвержденной информации о собственнике имущества, сделка с которым лежит в основе такого виртуального актива распределенного реестра, а также подтвержденной информации о принадлежащем объеме прав на такое имущество у создателя виртуального актива распределенного реестра.

Таким образом, соблюдение перечисленных выше условий является необходимым и достаточным для определения виртуального актива распределенного реестра в качестве товара, что обеспечивает его нахождение в рамках гражданского оборота. В свою очередь, в случае несоответствия всем перечисленным условиям виртуальный актив распределенного реестра не будет являться объектом гражданского оборота (товаром) и будет предназначен для использования в других, отличных от обмена, целях.

Возвращаясь к рассмотрению финансового учета в системе учета токенов распределенного реестра, необходимо также сказать о том, что на сегодняшний день стандартизация процессов финансовой отчетности в международных масштабах происходит на основе требований Международных стандартов финансовой отчетности (International Financial Reporting Standards Foundation, 2020) (далее - МСФО), разработкой и публикацией которых занимается независимый орган Фонда международных стандартов финансовой отчетности (ФМСФО) Совет по Международным стандартам финансовой отчетности (СМСФО). Важно отметить, что ведение финансового учета, осуществляемого в системе учета токенов распределенного реестра, посредством такого инструмента, как виртуальный актив распределенного реестра, имеет возможность быть организованным в соответствии с требованиями, которые содержатся в стандартах МСФО.

Управленческий учет. В свою очередь, в случае если в качестве инструмента, посредством которого будет осуществляться ведение учета имущества, будет виртуальный актив распределенного реестра, который не является объектом гражданского оборота и предназначен для использования в других, отличных от обмена, целях, то речь будет идти об управленческом учете имущества.

$\mathrm{He}$ находящийся в гражданском обороте виртуальный актив распределенного реестра как инструмент для реализации способа управленческого учета имущества может быть создан исключительно в процессе подготовки и заключения договора, в котором будет описано такое имущество, предназначенное для использования в других, отличных от обмена, целях.

Раскрывая вопрос целевого назначения управленческого учета, необходимо говорить о том, что в отличие от финансового такой вид учета может быть охарактеризован как учет, выполняемый для обеспечения соответствующей информацией прежде всего внутренних пользователей с целью контроля за производственно-хозяйственной деятельностью организации, для решения внутренних задач управления организацией, поиска и обоснования управленческих решений. Данные управленческого учета являются коммерческой тайной организации. Кроме того, методика и организация управленческого учета не регламентируется. Управленческий учет ведется по правилам, устанавливаемым самой организацией, с учетом специфики ее деятельности (Kulikova et al., 2014).

Важно отметить, что финансовый и управленческий учет имущества, осуществляемый с помощью системы учета токенов распределенного рееста посредством виртуального актива распределенного реестра, будет обладать высокой степенью достоверности в силу того, что технология распределенного реестра благодаря своим свойствам предоставляет принципиально качественно новый по своей надежности способ хранения и управления информацией.

Исходя из вышеизложенного, фундаментальной характеристикой для рассмотрения виртуального актива распределенного реестра в качестве инструмента, с помощью которого в системе учета токенов распределенного реестра осуществляется учет имущества, является наличие его правовой связи с имуществом, что в свою очередь детерминирует дальнейшее рассмотрение правовой составляющей экономико-правовой природы виртуального актива распределенного реестра.

Правовая природа представляет собой юридическую характеристику определенного явления, выражающую его специфику, место и функции среди других правовых явлений в соответствии с его социальной природой (Alekseev, 
2010). Правовую природу виртуальных активов распределенного реестра целесообразно рассматривать исходя из ее объектной и субъектной составляющих. Это позволяет определить правовой аспект виртуальных активов распределенного реестра, что, в свою очередь, станет базой для создания надлежащего правового режима виртуальных активов распределенного реестра.

Как было отмечено при рассмотрении технологической природы виртуальных активов распределенного реестра, распределенный реестр является системой учета, в основе которой находятся объекты учета в виде токенов распределенного реестра - объектов системы учета токенов распределенного реестра, являющихся идентификаторами структурированной определенным образом информации, которая может быть, но не исключительно, производной от исходного актива.

Из этого следуют два важных для рассмотрения правовой природы виртуальных активов распределенного реестра аспекта:

1. В случае отсутствия производности виртуального актива распределенного реестра от имущества - рассмотрение такого виртуального актива распределенного реестра в качестве объекта имущественных правоотношений (имущества в цифровом виде) (далее - криптоактив).

Как было отмечено ранее, токен распределенного реестра представляет собой основной инструмент распределенного реестра (Kud, 2020a). Иными словами, с позиции технологической составляющей виртуальные активы, которые создаются в системах учета токенов распределенного реестра, являются токенами распределенного реестра. Таким образом, для рассмотрения правовой природы виртуальных активов распределенного реестра в качестве криптоактивов в первую очередь необходимо рассмотреть атрибуты и свойства токена распределенного реестра.

По сравнению с объектами гражданских прав в целом категория «объекты права собственности» является менее обширной, потому что объектами права собственности не охватываются действия, результаты услуг и т. п. Объектом права собственности является имущество, состав которого, как правило, не детализируется, то есть в собственности может быть любое имущество (Borysova et al., 2011). Категория «имущество» является фундаментальным понятием цивилистики, поскольку именно она отражает универсальную характеристику основной массы общественных отношений, составляющих предмет гражданского права (Lysenko, 2010). Традиционно к имуществу относят объекты гражданских прав (деньги, ценные бумаги, результаты работ, услуг, результаты интеллектуальной деятельности, информацию, а также другие материальные и нематериальные блага), а также отдельного внимания заслуживают имущественные права (право пользования, право распоряжения и право владения объектом гражданских прав).

Раскрывая вопрос объектной составляющей, важно отметить, что проведенный в рамках технологической природы анализ единиц учета токена распределенного реестра как объекта позволяет говорить о том, что не токен распределенного реестра, а его единицы учета могут являться объектом имущественных правоотношений. Необходимо отметить, что количество единиц учета токена распределенного реестра может выступать единицами измерения объема прав по отношению к такому токену распределенного реестра.

Действительно, трудно даже представить, что запись в классическом реестре, например в бухгалтерской книге учета операций или в файле домашней бухгалтерии, то есть точно запись не в распределенном реестре, может выступать отдельным объектом сделки. Напротив, такая запись, скорее, может считаться результатом какого-либо юридического факта, повлиявшего на возникновение, изменение или прекращение правоотношений. В свою очередь, токен распределенного реестра как объект учета систем, реализованных на базе технологии распределенного реестра, может быть самостоятельным объектом имущественных отношений, имеющим собственные единицы учета в системе учета токенов распределенного реестра (Kud, 2020a) (см. Рисунок 1). Одними из самых известных мировому сообществу примеров криптоактивов являются токены распределенного peестра Bitcoin и Ethereum, так как у них нет связи с каким-либо видом имущественных прав. Эти виртуальные активы распределенного реестра являются криптоактивами на том основании, что при совершении перевода их единиц учета не будет осуществляться сделка с имуществом, находящимся вне системы учета токенов распределенного реестра.

2. В случае производности виртуального актива распределенного реестра от имущества рассмотрение такого виртуального актива распределенного реестра в качестве имущественного права в цифровом виде, производного от имущества (далее токенизированный актив).

Под имущественными правами принято понимать субъективные права субъектов гражданских правоотношений, которые связаны с их правомочиями в отношении объектов собственности (владением, пользованием и распоряжением имуществом), а также с материальными (имущественными) требованиями, возникающими в ходе гражданского оборота и имеющими денежное выражение.

Важно отметить, что в рассматриваемом случае токенизированный актив будет представлять собой имущественное право в цифровом виде, производное от имущества. Такое имущество для токенизированного актива будет исходным 
активом, а именно имуществом, право по распоряжению которым используется его собственником для создания токенизированного актива. В качестве исходного актива может выступать как непосредственно имущество, так и объем прав относительно имущества и пр.

Производность токенизированного актива от исходного актива определяется наличием правовой связи с конкретной сделкой, что проявляется во взаимных правах и обязанностях между собственником исходного актива и собственником токенизированного актива. Существует обязательное для создания токенизированного актива условие - он может быть создан и использован исключительно в результате сделки с исходным активом. Другими словами, токенизированного актива без сделки с исходным активом не может существовать. Токенизированный актив может быть создан исключительно в рамках осуществления сделки с конкретным имуществом и только как цифровое выражение уже существующего имущественного права, являющегося объектом такой сделки. Именно такое положение дел позволяет говорить о том, что эти виртуальные активы распределенного реестра являются токенизированными активами на том основании, что при совершении перевода их единиц учета будет осуществляться сделка с имуществом, находящимся вне системы учета токенов распределенного реестра, - исходным активом этого токенизированного актива.

Важно отметить, что именно по причине наличия в основе токенизированного актива сделки с исходным активом токенизированный актив выступает инструментом для осуществления финансового или управленческого учета такого исходного актива в системе учета токенов распределенного реестра.

Говорить об отношениях, возникающих в сфере применения виртуальных активов распределенного реестра, не учитывая и не разграничивая правовой статус субъектов таких отношений, некорректно. К данному вопросу необходимо подходить комплексно, устанавливая не только объектный, но и субъектный их состав.

Участников отношений в сфере применения виртуальных активов распределенного реестра можно определить как пользователей системы учета токенов распределенного реестра. При этом сама по себе система учета токенов распределенного реестра не предоставляет возможности идентификации своих пользователей по причине отсутствия программной архитектуры для создания учетных записей как хранимой совокупности данных о пользователях, необходимых для их идентификации, аутентификации и авторизации. Именно это обуславливает невозможность использования системы учета токенов распределенного реестра в качестве среды заключения сделки по причине того, что на действия пользователей системы учета токенов распределенного рееста не могут распространяться государственные гарантии, в частности возможность защиты законных прав и интересов пользователей, которые не были идентифицированы.

Таким образом, результатом рассмотрения экономико-правовой природы виртуального актива распределенного реестра стало его разделение на: - токенизированный актив - вид виртуального актива, который существует в системе учета токенов распределенного реестра в виде записи с идентификатором информации, производной от исходного актива. Токенизированный актив в случае его определения в качестве объекта гражданского оборота позволяет вести финансовый учет исходного актива. Тогда как посредством токенизированного актива негражданского оборота возможно осуществление управленческого учета исходного актива;

- криптоактив - вид виртуального актива, который существует в системе учета токенов распределенного реестра в виде записи с идентификатором информации, непроизводной от исходного актива.

Также в процессе исследования был рассмотрен субъектный состав отношений в сфере применения виртуальных активов распределенного реестра, в результате чего всех участников отношений в сфере применения виртуальных активов распределенного реестра можно определить как пользователей системы учета токенов распределенного реестра (далее - пользователи).

Таким образом, определив субъектно-объектный состав отношений в сфере применения виртуальных активов, можно говорить об установлении правового режима виртуальных активов распределенного реестра и правового статуса таких субъектов. Это очень важно для урегулирования отношений, которые возникают в сфере применения виртуальных активов распределенного реестра (Kud, 2020a).

Информационно-прикладная

природа токенизированных активов. Выйти на уровень классификации, который следует за уровнем, основывающимся на рассмотрении экономикоправовой природы, позволяет прикладная природа токенизированного актива как одна из составляющих его информационно-прикладной природы.

Прикладная природа токенизированного актива раскрывается посредством такого свойства управления единицами учета токена распределенного реестра, как их делимость или неделимость, рассмотрение которого необходимо проводить в комплексе с рассмотрением информационной природы.

Информационная природа токенизированных активов раскрывается через информационную составляющую токенизированного актива, которая присуща его исходному активу.

Если исходным активом для токенизированного актива является информационный ресурс, производный от первичного актива (далее - 
информационный ресурс цифрового актива), то речь будет идти о таком виде токенизированного актива, как цифровой актив децентрализованной информационной платформы (далее - цифровой актив).

Децентрализованная информационная платформа состоит из инфраструктуры сервисов и сообщества независимых пользователей, наделенных либо равными, либо заранее определенными правами, которые распределены по уровням децентрализованной модели управления для обеспечения устойчивости такой системы (Kud, 2021). Децентрализованная информационная платформа включает в себя систему учета токенов распределенного реестра и может быть использована в качестве среды заключения сделки, где контрагенты, идентифицированные децентрализованной информационной платформой, имеют учетные записи (личные кабинеты), а все действия автоматически регистрируются в такой платформе.

Поскольку децентрализованные информационные платформы являются результатом человеческой деятельности, то очевидно, что есть такие пользователи, которые обеспечивают поддержание работы таких платформ, а есть такие пользователи, чьи действия направлены на потребление полезных свойств данных платформ. Исходя из этого, пользователей информационной платформы можно классифицировать как «поставщиков услуг» и «потребителей услуг» (Рисунок 2).

\section{Рисунок 2}

Субъектный состав общественных отношений, осуществляемых на базе децентрализованной информационной платформьл

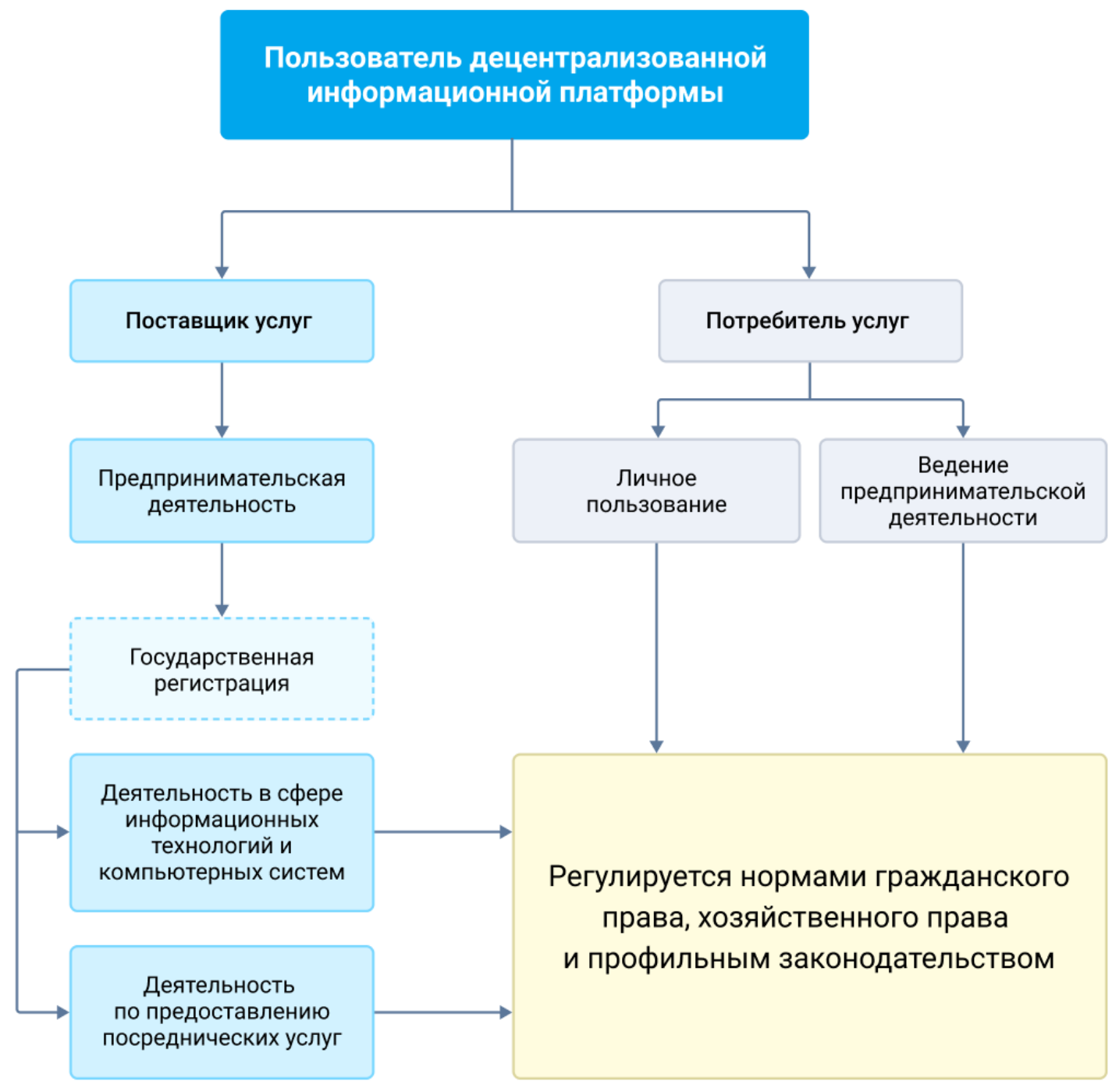

Деятельность поставщиков услуг может быть направлена на предоставление услуг другим пользователям, что, по сути, влечет за собой реализацию общественных отношений в децентрализованных информационных платформах с цифровыми активами как инструментами для реализации способов финансового и управленческого учета имущества. Цифровые активы и децентрализованные информационные платформы могут применяться для реализации 
любого рода отношений, в том числе коммерческой направленности, при этом сами цифровые активы также могут выступать объектом таких отношений. Отмечается, что деятельность поставщиков услуг является предпринимательской и определяется как деятельность в сфере информационных технологий и компьютерных систем или как посреднические услуги. В свою очередь, другие пользователи децентрализованных информационных платформ (потребители услуг) потребляют услуги для личного пользования, а также в целях ведения предпринимательской деятельности.

Общественные отношения, осуществляемые на базе децентрализованной информационной платформы, должны считаться договорными и подпадать под сферу регулирования гражданского и/или хозяйственного законодательств. Это обусловлено тем, что идентификация пользователей децентрализованной информационной платформы позволяет утверждать: на такого рода сделки могут распространяться государственные гарантии, в частности возможность защиты законных прав и интересов идентифицированных пользователей децентрализованной информационной платформы. Как инфраструктурное решение децентрализованная информационная платформа состоит из программных комплексов, которые могут быть реализованы в виде сервисов и компонентов.

Таким образом, проведенный в рамках нашего исследования анализ позволяет говорить о децентрализованной информационной платформе, которая является программно-аппаратным комплексом, инфраструктура которого состоит из компонентов и сервисов, включает систему учета токенов распределенного реестра и предоставляет своим пользователям возможность реализовывать имущественные и личные неимущественные отношения путем осуществления финансового и управленческого учета своих имущественных и личных неимущественных прав посредством цифровых активов.

Возможность создания учетных записей пользователей в децентрализованной информационной платформе как совокупности данных о пользователях, хранимой и необходимой для их идентификации, аутентификации и авторизации, а также существование комплекса компонентов и сервисов позволяют говорить о децентрализованной информационной платформе как о среде обращения цифровых активов. Только децентрализованная информационная платформа с eе компонентами и сервисами (как инфраструктурными решениями) позволяет создать информационную составляющую цифрового актива, представленную в виде информационного ресурса цифрового актива.

Важно отметить, что информационный ресурс цифрового актива является исходным активом для цифрового актива в децентрализованной информационной платформе, представляющим собой результат интеллектуальной деятельности, который создается собственником первичного актива в объеме имеющихся у него прав на первичный актив. Особого внимания заслуживает исключительность природы информационного ресурса цифрового актива, отличающая его от иных исходных активов. Производность цифрового актива от информационного ресурса цифрового актива определяется наличием правовой связи с конкретной сделкой в децентрализованной информационной платформе, объектом которой является информационный ресурс цифрового актива. Кроме того, в отличие от других исходных активов информационный ресурс цифрового актива находится в децентрализованной информационной платформе, что предоставляет ему дополнительные качества, среди которых «достоверность», «неизменность», «структурированность» и др. В случае с информационным ресурсом цифрового актива речь также идет о такой категории, как «первичный актив», производным от которого является информационный ресурс цифрового актива и который представляет собой имущество, существующее вне децентрализованной информационной платформы, право по распоряжению которым используется его собственником при формировании информационного ресурса цифрового актива как исходного актива для создания цифрового актива. Из этого следует, что для создания информационного ресурса цифрового актива, производного от первичного актива, крайне важным является наличие у децентрализованной информационной платформы программной архитектуры в виде инфраструктуры компонентов и сервисов, позволяющей создавать учетные записи для пользователей децентрализованной информационной платформы с целью их идентификации в процессе распоряжения имуществом, выполняющим роль первичного актива.

Возвращаясь к вопросу рассмотрения первичного актива, важно отметить, что он представляет собой значение ценности, важности, полезности чеголибо, которое также может выражаться различными единицами измерения в зависимости от области практического использования такого первичного актива и экосистемы, в которой есть такой первичный актив. Информация о таком имуществе как о первичном активе, в том числе информация о комплексе прав и ограничений на такое имущество, может содержаться в информационном ресурсе цифрового актива в объеме прав на имущество у создателя такого информационного ресурса цифрового актива, который является исходным активом для цифрового актива (Рисунок 3). 


\section{Рисунок 3}

Производность ичиррового актива

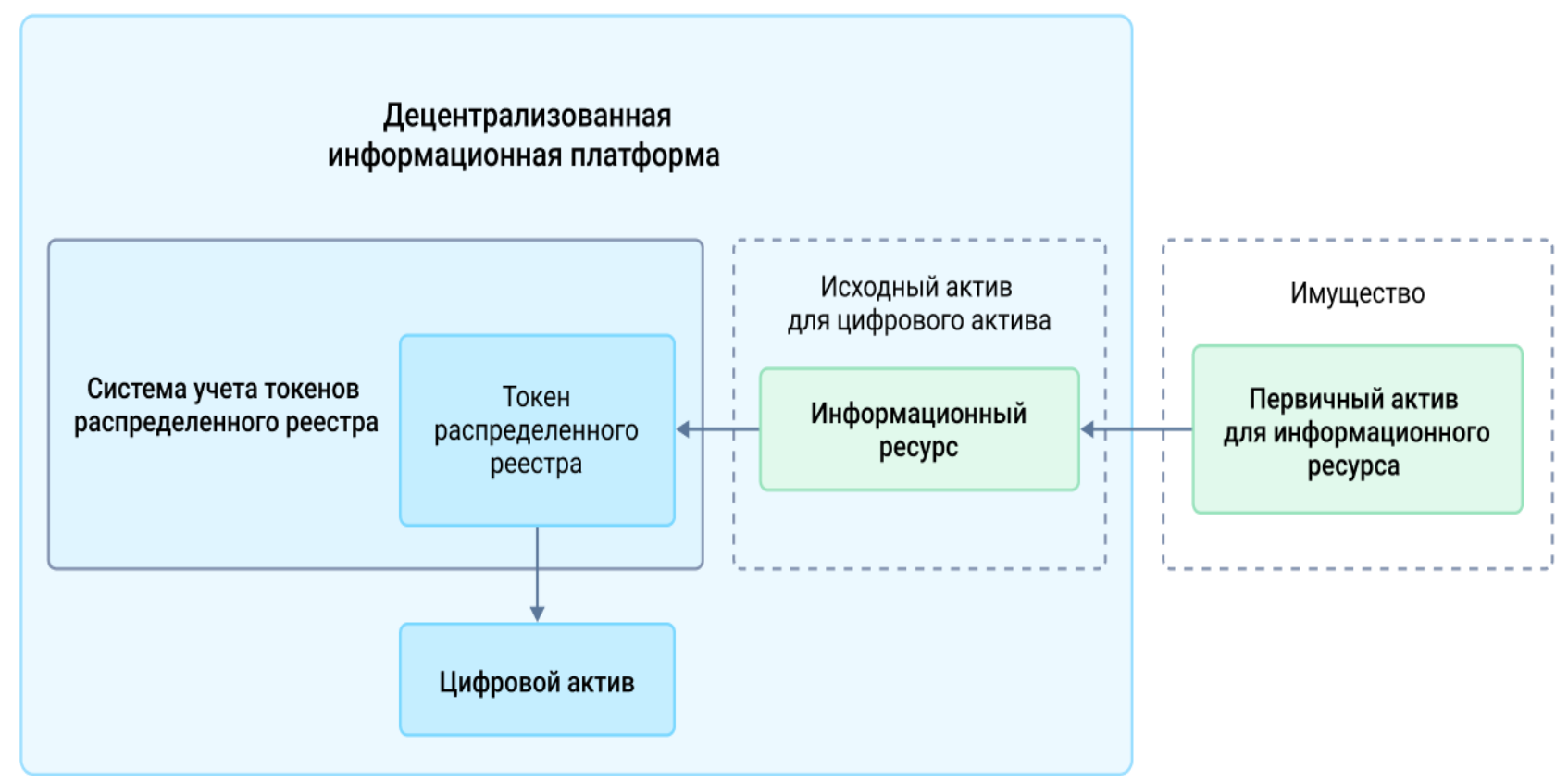

Отдельно следует отметить, что информационный ресурс цифрового актива как форму фиксации информации о первичном активе создает непосредственно собственник первичного актива. В свою очередь, этот принцип, а также определение информационного ресурса цифрового актива как самостоятельного объекта имущественных правоотношений обуславливают определение информационного ресурса цифрового актива в качестве объекта прав интеллектуальной собственности собственника первичного актива. Таким образом, производность информационного peсурса цифрового актива как исходного актива для цифрового актива и производного от первичного актива определяется наличием у создателя цифрового актива комплекса прав и обязанностей по распоряжению первичным активом.

Информационным ресурсом цифрового актива как исходным активом для цифрового актива, являющимся объектом прав интеллектуальной собственности, можно распоряжаться только в децентрализованной информационной платформе и только на праве пользования. Также стоит отметить, что информационный ресурс цифрового актива как объект прав интеллектуальной собственности для целей финансового учета будет определяться на основе требований МСФО 38 «Нематериальные активы» от 01.01.2012 г. (Joyce, 2017) в качестве нематериального актива (НМА).

Технически единицы учета цифрового актива являются единицами учета объема прав на доступ к информационному ресурсу цифрового актива, производному от права на первичный актив. Другими словами, цифровой актив представляет собой право пользования интеллектуальной собственностью собственника первичного актива - информацией как объектом прав интеллектуальной собственности, то есть конкретным имуществом. Таким образом, объектом правоотношений собственников цифровых активов является не первичный актив, а единицы учета цифрового актива. При передаче единиц учета цифрового актива передается определенный объем прав на доступ к информационному ресурсу цифрового актива, где содержится информация, которая была заложена собственником первичного актива касательно комплекса прав на первичный актив и сведений об обязательствах собственника первичного актива. Необходимо отметить, что при обращении цифрового актива, то есть обмене его единиц учета, также происходит обмен определенного объема прав на имущество, выраженное в количестве единиц учета такого цифрового актива.

Рассмотрение основного свойства цифрового актива и установление связи между цифровым активом как единицей объема допуска (права на доступ) к информационному ресурсу цифрового актива и правом собственности на первичный актив позволяют говорить об отдельном объекте гражданских правоотношений - информационном ресурсе цифрового актива. Таким образом, цифровой актив представляет собой инструмент для реализации способа использования информации о первичном активе, которая представлена в децентрализованной информационной платформе в виде информационного ресурса цифрового актива, что открывает новые возможности для оперирования комплексом прав на первичный актив (Kud, Kucheriavenko, \& Smychok, 2019).

Также необходимо более детально рассмотреть составляющие цифрового актива: 
- экономическая составляющцая представлена в финансовой сфере наличием идентификатора (Kud, 2019b). Идентификатор представляет собой атрибутивный признак объекта учета, служащий для его идентификации, который выражен в виде уникального набора буквенных и/или цифровых символов определенной длины и присваивается объекту учета в среде его обращения. Идентификатор применяется в информационных системах и предназначен для идентификации определенного объекта в сети, а также позволяет исключить любую вероятность дублирования этого объекта и подтверждает его подлинность (Kud, 2019b). В случае с цифровым активом посредством идентификатора осуществляется ведение учета имущества (информационного ресурса цифрового актива как исходного актива, а также любого имущества как первичного актива). При этом в случае определения цифрового актива как объекта гражданского оборота такой учет имущества будет иметь финансовый характер. Если же цифровой актив определяется как объект негражданского оборота, то речь будет идти об управленческом учете. Важно отметить, что в качестве идентификатора информационного ресурса цифрового актива, производного от первичного актива, выступает токен распределенного реестра как объект учета в системе учета токенов распределенного реестра;

- правовая составляющая представлена в юридической сфере производной от права (Kud, 2019b). Возможность реализации объекта, обладающего характеристикой производности от права, обуславливается тем, что единицы учета цифрового актива обращаются только в децентрализованной информационной платформе, которая является программно-аппаратным комплексом, инфраструктура которого состоит из компонентов и сервисов, включает систему учета токенов распределенного реестра и предоставляет своим пользователям возможность реализовывать имущественные и личные неимущественные отношения путем осуществления финансового и управленческого учета своих имущественных и личных неимущественных прав посредством цифровых активов;

- информационная составляющая представлена в сфере информационных технологий компонентой «информационный ресурс цифрового актива», права на который обращаются в распределенном реестре посредством единиц учета токена распределенного реестра. Для цифрового актива наличие информационного ресурса цифрового актива как объекта, используемого в качестве исходного актива, выступает его характеристикой, отличительной от других токенизированных активов;

- ценностная составляющая представлена в сфере материальных и нематериальных благ компонентой «ценность» (Kud, 2019b). Как было отмечено ранее, речь идет о первичном активе, который определяется как ценность в силу того, что является имуществом, существующем вне децентрализованной информационной платформы, право по распоряжению которым используется его собственником при формировании информационного ресурса цифрового актива как исходного актива для создания цифрового актива. Таким образом, первичный актив представляет собой значение ценности, важности, полезности чего-либо, которое также может выражаться различными единицами измерения в зависимости от области практического использования такого первичного актива и экосистемы, в которой есть такой первичный актив.

Из проведенного выше анализа следует, что понятие «цифровой актив» имеет свои сущностносмысловые особенности, представленные составляющими (экономической, правовой, информационной, ценностной), которые имеют взаимосвязь и взаимозависимость. Эта связь проиллюстрирована на Рисунке 4.

\section{Рисунок 4}

Сущуностно-смысловые особенности понятия «циифровой актив» в экономико-правовом аспекте

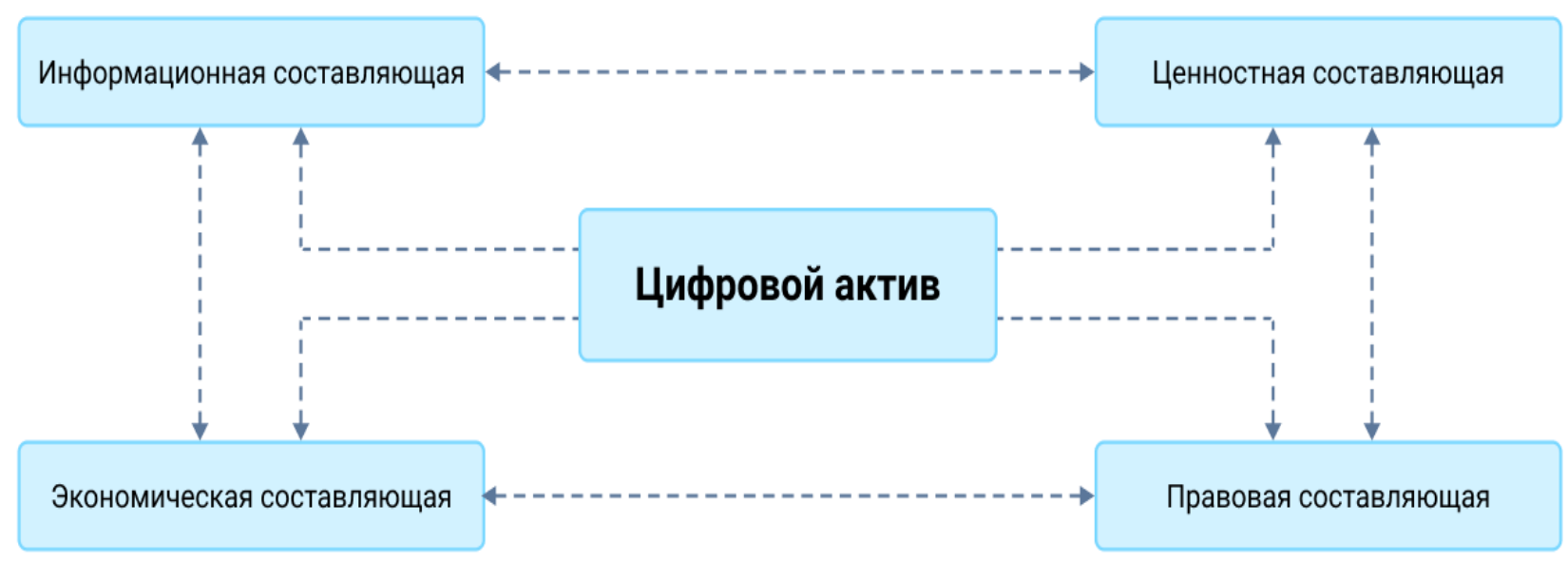


Таким образом, цифровой актив информационный ресурс, производный от права на ценность и обращающийся в распределенном реестре в виде уникального идентификатора (Kud, 2019b). В качестве примера цифрового актива можно привести цифровой актив Bitbon, производный от права пользования немонетарным активом (Kud, 2020b), а также иные цифровые активы, которые могут быть созданы в Системе Bitbon (Bitbon System, 2020) - децентрализованной информационной платформе, инфраструктура которой позволяет Пользователям Системы Bitbon реализовывать имущественные и личные неимущественные отношения путем осуществления финансового и управленческого учета своих имущественных и личных неимущественных прав посредством своих цифровых активов.

Если исходным активом для токенизированного актива является имущество, отличное от информационного ресурса цифрового актива, производного от первичного актива, то речь будет идти о следующих видах токенизированного актива:

- полиактив системы учета токенов распределенного реестра (далее - полиактив) как цифровое отображение имущественного права, возникающего из прав кредитора и обязанностей должника договора по распоряжению исходным активом, и учет которого осуществляется с помощью множества единиц учета. Другими словами, полиактив как договор (оферта), в котором один должник и множество кредиторов, средой фиксации которого выступила система учета токенов распределенного реестра;

- моноактив системы учета токенов распределенного реестра (далее - моноактив) как цифровое отображение имущественного права, возникающего из прав кредитора и обязанностей должника договора по распоряжению исходным активом, учет которого осуществляется с помощью неделимого объема единиц учета. Другими словами, моноактив как договор (оферта), в котором один должник и один кредитор, средой фиксации которого выступила система учета токенов распределенного реестра.

Раскрывая суть такой категории, как «полиактив», важно отметить, что к полиактивам относятся известные виртуальные активы распределенного реестра, такие как:

- стейблкоины (в случае, если в основе полиактива лежит сделка с деньгами как объектом имущественных правоотношений). Одним из известных примеров такого полиактива, как стейблкоин, является Tether (USDT), стоимость которого обеспечивается хранящимися на счетах создавшей его компании Tether Limited долларами США;

- различного рода инвестиционные полиактивы (в основе которых находится сделка с ценными бумагами как объектом имущественных правоотношений);
- такие полиактивы, которые создаются для целей проведения ICO (Initial coin offering - первичное предложение монет (токенов распределенного реестра)), в основе которых находится сделка с информацией об имуществе в качестве исходного актива, и пр.

Для моноактива характерно то, что он может быть определен в качестве цифрового отображения имущественного права, возникающего из прав кредитора и обязанностей должника договора по распоряжению исходным активом, учет которого осуществляется с помощью неделимого объема единиц учета, что позволяет говорить о моноактиве как договоре (оферте), в котором один должник и один кредитор и средой фиксации которого выступила система учета токенов распределенного реестра. В свою очередь, это обуславливает следующие особенности моноактива:

- идентификатор моноактива одновременно может являться номером договора;

- невозможность делимости передаваемых единиц учета моноактива в связи с неделимостью объема прав на исходный актив, описанных в договоре.

Другими словами, в результате осуществления одной транзакции в системе учета токенов распределенного реестра происходит передача неделимого объема единиц учета моноактива от одного пользователя к другому, равного 100\% прав на его исходный актив.

В качестве примеров моноактивов можно привести такие виртуальные активы распределенного реестра, которые обладают свойством невозможности делимости их единиц учета в связи с неделимостью объема прав на исходный актив, которые создаются авторами объектов интеллектуальной собственности в системе учета токенов распределенного реестра под названием WIPO PROOF (World Intellectual Property Organization, 2020) с целью осуществления учета своих авторских прав в отношении таких объектов интеллектуальной собственности.

В отношении представленных на Рисунке 5 составляющих полиактива и моноактива важно отметить, что полиактив и моноактив обладают теми же экономической и правовой составляющими, что и цифровой актив. Тогда как информационная составляющая полиактива и моноактива, в отличие от цифрового актива, представлена наличием исходного актива, в качестве которого выступает любое имущество (отличное от информационного ресурса, производного от первичного актива), право по распоряжению которым используется его собственником для создания токенизированного актива. В свою очередь такая характеристика исходного актива обуславливает отсутствие ценностной составляющей у полиактива и моноактива, которая у цифрового актива представлена первичным активом. 
Рисунок 5

Производность полиактива и моноактива

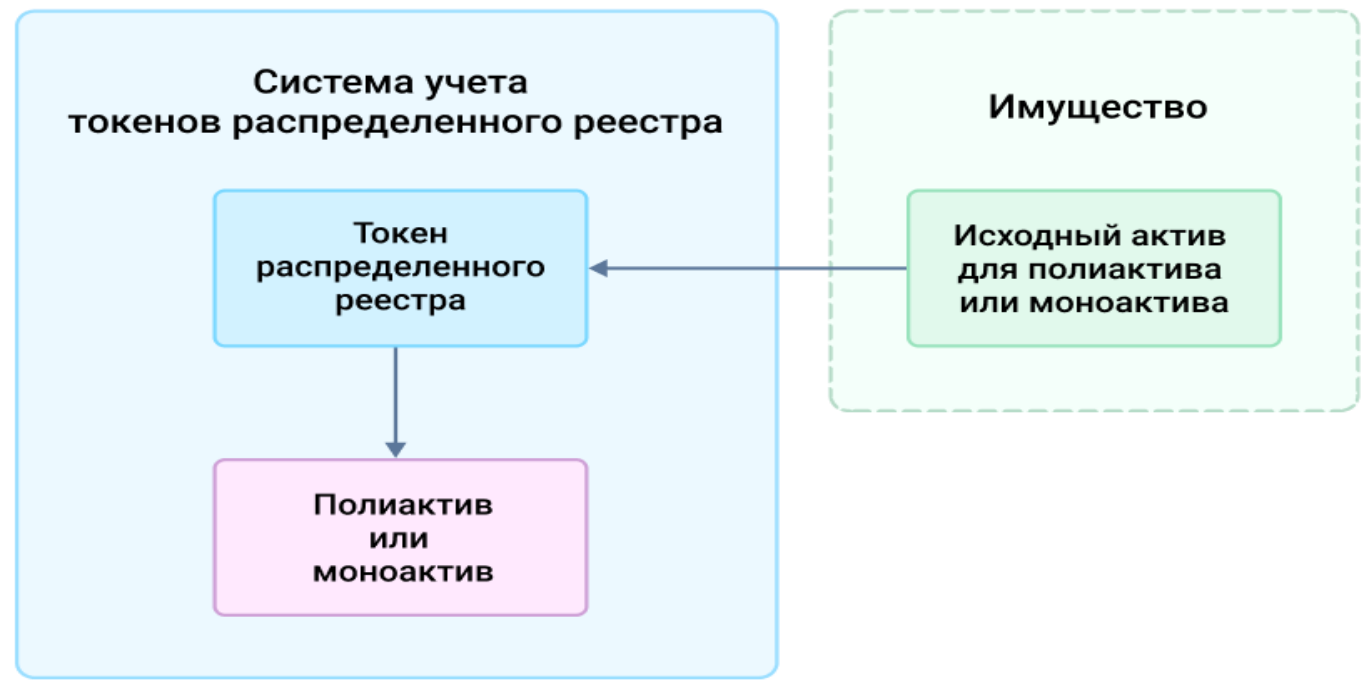

В рамках рассмотрения вопроса информационноприкладной природы важно также отметить, что многоцелевое назначение цифрового актива и полиактива обуславливает возможность делимости их единиц учета, а также в случае с цифровым активом - и неделимости его единиц учета. Так, единица учета полиактива соответствует определенному объему имущественного права, производного от исходного актива, и должна быть больше минимального неделимого числового значения делимого объема прав распоряжения на исходный актив (обозначено в Таблице 1 как «>

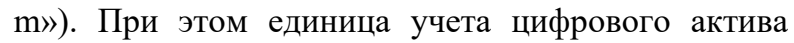
соответствует определенному объему прав на доступ к информационному ресурсу цифрового актива, производному от первичного актива, и может быть равна или больше минимального неделимого числового значения делимого объема прав пользования на исходный актив (обозначено в Таблице 1 как « т»). Для моноактива же, не обладающего многоцелевым назначением, характерно свойство невозможности делимости передаваемых его единиц учета в связи с неделимостью объема прав на его исходный актив (обозначено в Таблице 1 как «т»).

Таким образом, соотношение категорий «цифровой актив», «полиактив» и «моноактив», которое основывается на проведенном исследовании информационно-прикладной природы виртуальных активов распределенного реестра, отображено в Таблице 1.

\section{Таблица 1}

Соотношение свойств разных видов виртуальных активов распределенного реестра, производных от исходного актива

\begin{tabular}{cccc}
\hline $\begin{array}{c}\text { Вид виртуального актива } \\
\text { распределенного реестра }\end{array}$ & $\begin{array}{c}\text { Единицы учета токена } \\
\text { распределенного реестра }\end{array}$ & $\begin{array}{c}\text { Свойство управления } \\
\text { единицами учета токена } \\
\text { распределенного реестра }\end{array}$ & $\begin{array}{c}\text { Производность } \\
\text { от информационного } \\
\text { ресурса цифрового } \\
\text { актива }\end{array}$ \\
\hline Цифровой актив & $\geq \mathrm{m} . . \mathrm{n}$ & Делимость/неделимость & + \\
Полиактив & $>\mathrm{m} . . \mathrm{n}$ & Делимость & - \\
Моноактив & $\mathrm{m}$ & Неделимость & - \\
\hline
\end{tabular}

Таким образом, экономико-правовая природа токенизированных активов и информационноприкладная природа видов токенизированных активов (Рисунок 6) позволяют рассматривать:

- моноактив как договор (оферту), в соответствии с которым могут реализоваться взаимные обязательства только одного должника (собственника исходного актива) и одного кредитора (собственника единиц учета моноактива);

- полиактив как договор (оферту), в соответствии с которым могут реализоваться взаимные обязательства только одного должника (собственника исходного актива) и множества кредиторов (собственников единиц учета полиактива);

- циифровой актив как договор (оферту), в соответствии с которым могут реализоваться взаимные обязательства должника (собственника исходного актива в виде информационного ресурса цифрового актива), а также множества должников (собственников первичных активов) и множества кредиторов (собственников единиц учета цифрового актива). 
Рисунок 6

Производность видов токенизированных активов от имущества

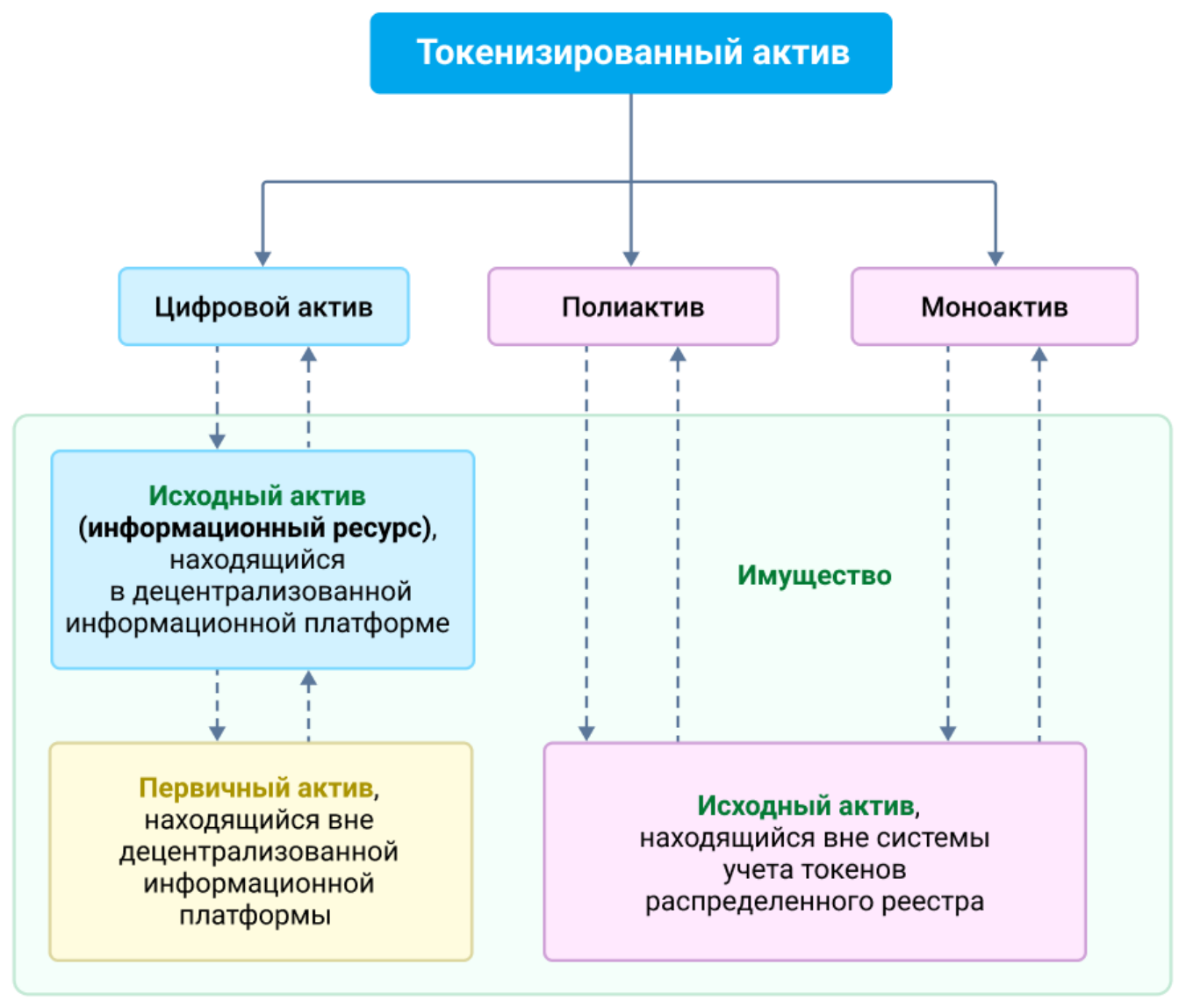

Важно отметить, что к основным свойствам и параметрам токенизированных активов относятся: - наличие данных токена распределенного реестра, представляющих собой совокупность атрибутов и свойств токена распределенного реестра: хеш токена распределенного реестра, хеши транзакций, количество единиц учета токена распределенного реестра и адрес хранения единиц учета такого токена распределенного реестра, а также других атрибутов и свойств, которые могут быть определены разработчиком (создателем) умного контракта такого токена распределенного реестра. Наличие у токенизированного актива данных токена распределенного реестра обуславливает следующий параметр;

- обращение в системе учета токенов распределенного реестра, представляющей информационную систему регистрации, хранения, обмена данными токенов распределенного реестра, которая основана на технологии распределенного реестра;

- наличие исходного актива, а именно имущества, право по распоряжению которым используется его собственником для создания токенизированного актива;

- наличие информационного ресурса цифрового актива, являющегося исходным активом для цифрового актива в децентрализованной информационной платформе, представляющий собой результат интеллектуальной деятельности, который создается собственником первичного актива в объеме имеющихся у него прав на первичный актив;

- наличие первичного актива, производным от которого является информационный ресурс цифрового актива и который представляет собой имущество, существующее вне децентрализованной информационной платформы, право по распоряжению которым используется его собственником при формировании информационного ресурса цифрового актива как исходного актива для создания цифрового актива; - хранение информационного ресурса цифрового актива в децентрализованной информационной платформе, которая является программноаппаратным комплексом, инфраструктура которого состоит из компонентов и сервисов, включает систему учета токенов распределенного реестра и предоставляет своим пользователям возможность реализовывать имущественные и личные неимущественные отношения путем осуществления финансового и управленческого учета своих имущественных и личных неимущественных прав посредством цифровых активов. Отличительной характеристикой децентрализованной информационной платформы является еe инфраструктура компонентов и сервисов, позволяющая среди прочего создавать 
информационный ресурс цифрового актива, а также создавать учетные записи для пользователей такой системы с целью их идентификации в процессе распоряжения имуществом, формируя таким образом субъектный состав для осуществления имущественных и личных неимущественных прав посредством цифровых активов.

Разные сочетания основных свойств и параметров токенизированного актива позволяют выделить такие его виды, как «моноактив», «полиактив» и «цифровой актив» (Таблица 2).

Таблица 2

Основные свойства и параметры видов токенизированных активов

\begin{tabular}{|c|c|c|c|}
\hline \multirow{2}{*}{ Свойства и параметры } & \multicolumn{3}{|c|}{ Токенизированные активы } \\
\hline & Моноактив & Полиактив & Цифровой актив \\
\hline $\begin{array}{l}\text { Наличие данных токена } \\
\text { распределенного реестра }\end{array}$ & + & + & + \\
\hline $\begin{array}{l}\text { Обращение в системе учета } \\
\text { токенов распределенного реестра }\end{array}$ & + & + & + \\
\hline Наличие исходного актива & + & + & + \\
\hline $\begin{array}{l}\text { Наличие информационного } \\
\text { ресурса цифрового актива }\end{array}$ & - & - & + \\
\hline Наличие первичного актива & - & - & + \\
\hline $\begin{array}{l}\text { Хранение информационного } \\
\text { ресурса цифрового актива в } \\
\text { децентрализованной } \\
\text { информационной платформе }\end{array}$ & - & - & + \\
\hline Делимость единиц учета & - & + & + \\
\hline
\end{tabular}

\section{Виды виртуальных активов}

В основе построения многоуровневой классификации виртуальных активов как инструментов для реализации способов финансового и управленческого учета имущества находится принцип комплексности природы виртуального актива. Данный принцип нацелен на отображение комплексной природы виртуального актива посредством рассмотрения ее составляющих: технологической, экономикоправовой и информационно-прикладной природы.

Первый уровень классификации основывается на рассмотрении технологической природы виртуальных активов и позволяет выделить следующие виды:

1. Виртуальный актив распределенного реестра, который по своей сути является видом виртуального актива, представленного в системе учета токенов распределенного реестра в виде определенного количества единиц учета токена распределенного реестра, которые в таких системах учета представлены в виде уникальных идентификаторов.

2. Виртуальный актив нераспределенного реестра, определяемый в качестве вида виртуального актива, созданного на базе иной технологии, отличной от технологии распределенного реестра.

В качестве примеров виртуальных активов нераспределенного реестра можно привести: монеты в компьютерных играх, электронные деньги, бездокументарные ценные бумаги, цифровые абонементы, цифровые подарочные сертификаты и пр. Каждый из этих объектов является достаточно изученным и наделен своим, учитывающим все особенности объекта, правовым режимом.

На наш взгляд, уже на рассматриваемом уровне несложно заметить, что разные виды виртуальных активов, в частности рассматриваемые «виртуальный актив распределенного реестра» и «виртуальный актив нераспределенного реестра», имеют разную природу функционирования и реализации, и, соответственно, подходы к регулированию таких объектов должны учитывать ее особенности, вследствие чего регулирование будет разным (Kud, 2020a) в отношении их применения.

Второй уровень классификации основывается на исследовании экономико-правовой природы виртуальных активов распределенного реестра в силу того, что виртуальные активы нераспределенного реестра являются сравнительно изученным комплексным объектом и не представляют интереса с учетом обозначенной для данной работы цели исследования.

В рамках второго уровня классификации были выделены следующие виды виртуальных активов распределенного реестра:

1. Токенизированный актив, определяемый в качестве вида виртуального актива, который существует в системе учета токенов распределенного реестра в виде записи с идентификатором информации, производной от исходного актива.

Токенизированный актив является имущественным правом в цифровом виде, производным от 
имущества (исходного актива). Существует обязательное для создания токенизированного актива условие - он может быть создан и использован исключительно в результате сделки с исходным активом. Другими словами, токенизированного актива без сделки с исходным активом не может существовать. Токенизированный актив может быть создан исключительно в рамках осуществления сделки с конкретным имуществом и только как цифровое выражение уже существующего имущественного права, являющегося объектом такой сделки. Токенизированный актив в случае его определения в качестве объекта гражданского оборота позволяет вести финансовый учет исходного актива. При этом посредством токенизированного актива негражданского оборота возможно осуществление управленческого учета исходного актива.

Лексико-этимологический анализ термина «токенизированный актив» указывает на то, что он является имуществом. Токенизированный актив, являясь объектом имущественных правоотношений, существует только в системе учета токенов распределенного реестра в виде записи с идентификатором информации, производной от исходного актива.

Составляющая «токенизированный» указывает на ключевую характеристику рассматриваемого термина, а именно на то, что токенизированный актив не только сам по себе является имуществом. Токенизированный актив представляет собой вид виртуального актива, средство удостоверения обязательственных и иных прав, в том числе прав доступа к продуктам и услугам, прав на определенный продукт или услугу, прав на получение фиксированного дохода или процента от прибыли, прав управления, прав на покупку определенного актива по определенной цене в будущем (Eurasian Economic Commission, 2019).

Операции с токенизированными активами по своей сути являются договорными отношениями и должны подпадать под нормы гражданского права и хозяйственного права (в зависимости от субъектного состава отношений) (Kud, 2020a).

2. Криптоактив (от англ. сrypto криптографический), представляющий собой вид виртуального актива, который существует в системе учета токенов распределенного реестра в виде записи с идентификатором информации, непроизводной от исходного актива.

Лексико-этимологический анализ термина «криптоактив» указывает на то, что он является имуществом в криптографическом виде, которому в системе учета токенов распределенного реестра присвоен идентификатор (Kud, 2019b). Понятие «криптоактив» является общепринятым в профессиональной среде, отражает технологическую сторону данного явления: результат соединения криптографических технологий и технологии распределенного реестра (Eurasian Economic Commission, 2019), и является единственно верным для использования данного понятия на законодательном уровне.

Криптоактив является объектом имущественных правоотношений (имуществом в цифровом виде). В силу объективного отсутствия производности и обеспеченности криптоактивов каким-либо имуществом или имущественными правами операции с ними предлагается классифицировать как «финансовые операции с высокими рисками» и, как следствие, отнести их к сфере регулирования субъектами государственного финансового мониторинга и профильным законодательством соответственно (Kud, 2020a).

Третий уровень классификации приоритизирует изучение характеристик токенизированного актива в силу определения данного объекта в качестве перспективного направления с точки зрения его исследовательского потенциала и дальнейшего применения в экономике и праве.

В рамках этого уровня классификации были выделены следующие виды токенизированных активов:

\section{1. Цифровой актив децентрализованной} информационной платформы, который по своей сути является видом токенизированного актива и представляет собой цифровое отображение права пользования информационным ресурсом цифрового актива, производным от первичного актива.

Понятие «цифровой актив» состоит из следующих частей:

- «актив», который является разновидностью имущества, представляющего собой ресурс, который контролируется предприятием в результате прошлых событий и от которого предприятие ожидает получить будущие экономические выгоды (Ministry of Finance of the Russian Federation, 1999). Таким образом, значение термина «цифровой актив» указывает на то, что он является имуществом;

- «цифровой», который указывает на то, что цифровой актив, являясь объектом имущественных правоотношений, при этом существует только в цифровом пространстве, а именно в децентрализованной информационной платформе в виде записи с идентификатором информации, производной от информационного ресурса цифрового актива, который, в свою очередь, производный от первичного актива.

В децентрализованных информационных платформах имуществом, которое может стать исходным активом для токенизированного актива гражданского оборота, является информационный ресурс цифрового актива, то есть информация как целостный ресурс. Это означает, что токенизированный актив гражданского оборота в цифровом пространстве можно получить в качестве инструмента для реализации способа финансового или управленческого учета первичного актива цифрового актива.

В основе определения токенизированного актива как цифрового актива децентрализованной 
информационной платформы находится установление в качестве его исходного актива информационного ресурса цифрового актива, производного от первичного актива. Информационный ресурс цифрового актива является самостоятельным объектом правоотношений и представляет собой форму фиксации информации о первичном активе, которую создает непосредственно собственник первичного актива, в силу чего информационный ресурс цифрового актива является объектом прав интеллектуальной собственности собственника первичного актива. Таким образом, производность информационного ресурса цифрового актива как исходного актива для цифрового актива, производного от первичного актива, определяется наличием у создателя цифрового актива комплекса прав и обязанностей по распоряжению первичным активом. Информационный ресурс цифрового актива представляет собой отдельный вид имущества, тогда как цифровой актив децентрализованной информационной платформы является отображением имущественного права, производного от информационного ресурса цифрового актива.

В соответствии со своей правовой составляющей единицы учета цифрового актива являются единицами учета объема прав на доступ к информационному ресурсу цифрового актива, производному от первичного актива. При передаче единиц учета цифрового актива передается определенный объем прав на доступ к информационному ресурсу цифрового актива, где содержится информация, которая была заложена собственником первичного актива касательно комплекса прав на первичный актив и сведений об обязательствах собственника первичного актива (Kud, Kucheriavenko, \& Smychok, 2019).

Так как единицы учета цифрового актива соответствуют определенному объему прав на доступ к информационному ресурсу цифрового актива как его исходному активу, производному от первичного актива, то они обладают свойством делимости или неделимости. Таким образом, единицы учета цифрового актива являются инструментом передачи объема права на доступ к информационному ресурсу цифрового актива от одного пользователя децентрализованной информационной платформы к другому.

Цифровой актив в случае его определения в качестве объекта гражданского оборота позволяет вести финансовый учет информационного ресурса цифрового актива как исходного актива и любого имущества как первичного актива. Если цифровой актив определяется как объект негражданского оборота, то посредством такого цифрового актива возможно осуществлять только управленческий учет.

2. Моноактив системь учета токенов распределенного реестра, который определяется как вид токенизированного актива, единицы учета которого обладают свойством неделимости, так как соответствуют неделимому объему прав на исходный актив.

Для моноактива характерно то, что в качестве его исходного актива выступает любое другое имущество, отличное от информационного ресурса цифрового актива, производного от первичного актива.

Понятие «моноактив» состоит из следующих частей:

- «актив», который является разновидностью имущества, представляющего собой ресурс, который контролируется предприятием в результате прошлых событий и от которого предприятие ожидает получить будущие экономические выгоды (Ministry of Finance of the Russian Federation, 1999). Таким образом, значение термина «моноактив» указывает на то, что он является имуществом;

- «моно» (от греч. monos - один) - указывает на отсутствие многоцелевого назначения $\mathrm{y}$ моноактива в силу того, что этот вид токенизированного актива определяется исключительно в качестве договора (оферты), в котором один должник и один кредитор, а средой фиксации таких правоотношений выступает система учета токенов распределенного реестра.

Определение моноактива в качестве вышеуказанного договора (оферты) обуславливает невозможность делимости передаваемых единиц учета моноактива в связи с неделимостью объема прав на исходный актив, описанных в договоре. Таким образом, в результате осуществления одной транзакции в системе учета токенов распределенного реестра происходит передача неделимого объема единиц учета моноактива от одного пользователя к другому, равного 100\% прав на исходный актив такого моноактива.

3. Полиактив системь учета токенов распределенного реестра, который по своей сути является видом токенизированного актива, единицы учета которого обладают свойством делимости, количество которых соответствует определенному объему делимого имущественного права, производного от исходного актива.

Для полиактива характерно то, что в качестве его исходного актива выступает любое другое имущество, отличное от информационного ресурса цифрового актива, производного от первичного актива.

Понятие «полиактив» состоит из следующих частей:

- «актив», который является разновидностью имущества, представляющего собой ресурс, который контролируется предприятием в результате прошлых событий и от которого предприятие ожидает получить будущие экономические выгоды (Ministry of Finance of the Russian Federation, 1999). Таким образом, значение термина «полиактив» указывает на то, что он является имуществом;

- «поли» (от др.-греч. $\pi о \lambda v ́ \varsigma-$ многочисленный), что обозначает «большое количество», «множество», - 
указывает на наличие у полиактива многоцелевого назначения в силу того, что этот вид токенизированного актива определяется в качестве договора (оферты), в котором один должник и множество кредиторов, а средой фиксации таких правоотношений выступает система учета токенов распределенного реестра.

Как и для других видов токенизированных активов, для создания полиактива системы учета токенов распределенного реестра существует обязательное условие - он может быть создан и использован исключительно в результате сделки с исходным активом. Другими словами, полиактива без сделки с исходным активом не существует. Полиактив может быть создан исключительно в рамках осуществления сделки с конкретным имуществом и только как цифровое выражение уже существующего имущественного права, являющегося объектом такой сделки.
Так как количество единиц учета полиактива соответствует определенному объему делимого имущественного права, производного от его исходного актива, то они обладают свойством делимости. Таким образом, единицы учета полиактива являются инструментом передачи объема имущественных прав в отношении его исходного актива от одного пользователя системы учета токенов распределенного реестра к другому. Подход, выбранный для создания классификации виртуальных активов как инструментов для реализации способов финансового и управленческого учета имущества, учитывает многогранность их технологической, экономикоправовой и информационно-прикладной природы и, как результат, основывается на принципе комплексности природы виртуальных активов (Таблица 3).

\section{Таблица 3}

Классификация виртуальных активов как инструментов для реализации способов финансового и управленческого учета имущества

\begin{tabular}{ll}
\hline \multicolumn{1}{c}{ Природа } & \multicolumn{1}{c}{ Вид } \\
\hline Технологическая & Виртуальный актив распределенного реестра \\
Экономико-правовая & Виртуальный актив нераспределенного реестра \\
& Токенизированный актив \\
Информационно-прикладная & Криптоактив \\
& Цифровой актив \\
& Полиактив \\
& Моноактив \\
\hline
\end{tabular}

Предложенный в данной статье подход к классификации виртуальных активов как инструментов для реализации способов финансового и управленческого учета имущества является основой для создания правовой базы с целью объективного регулирования отношений в сфере применения виртуальных активов, а также значительно упраздняет финансовые и административные требования к субъектам правоотношений в сфере применения виртуальных активов (пользователям систем учета токенов распределенного реестра, пользователям децентрализованных информационных платформ, а также к поставщикам и потребителям услуг).

\section{Выводы}

За более чем десять лет своего существования технология распределенного реестра значительно эволюционировала и прошла несколько этапов, так называемых поколений (Kud, Kucheriavenko, \& Smychok, 2019; Pypenko \& Kud, 2019). Однако установление правового режима для инструментов распределенного реестра и закрепление в нормах права регламентирования их применения все еще остается важной нерешенной проблемой. В целом же в отношении распределенного реестра перед законодателем стоит ряд актуальных задач, решение которых гарантирует защиту прав участников правоотношений, реализованных на базе технологии распределенного реестра (Kud, 2020a).

Первой, кто предложил обобщающее название для всех видов инструментов, созданных на базе технологии распределенного реестра, которое учитывает их дифференцированную природу, а именно понятие «виртуальный актив», была Группа разработки финансовых мер борьбы с отмыванием денег (Financial Action Task Force, 2012).

Исследование, проведенное нами и направленное на изучение механизмов возможного использования виртуальных активов в разных секторах экономики, предлагает классификацию виртуальных активов как инструментов для реализации способов финансового и управленческого учета имущества, разграничение которых строится исходя из их дифференцированной технологической, экономикоправовой и информационно-прикладной природы, то есть на основании комплексности их природы, и определяет следующую систему классификации виртуальных активов:

- первый уровень классификации (основан на рассмотрении технологической природы) разделение виртуального актива на виртуальный 
актив распределенного реестра и виртуальный актив нераспределенного реестра;

- второй уровень классификации (основан на рассмотрении экономико-правовой природы) разделение виртуального актива распределенного реестра на токенизированный актив и криптоактив; - третий уровень классификации (основан на рассмотрении информационно-прикладной природы) - разделение токенизированного актива на цифровой актив, полиактив и моноактив.
Важно отметить, что обоснованные в рамках третьего уровня виды токенизированных активов: «цифровой актив», «полиактив» и «моноактив», можно применять как базовую модель в целях определения следующих уровней классификации для реализации способов финансового и управленческого учета (Рисунок 7) имущества, которое в силу своей природы может иметь разные правовые режимы, определяемые органами государственной власти в зависимости от целевого назначения конкретного имущества.

\section{Рисунок 7}

Графическое отображение реализащии способов финансового и управленческого учета имущества с помощью токенизированных активов разных видов

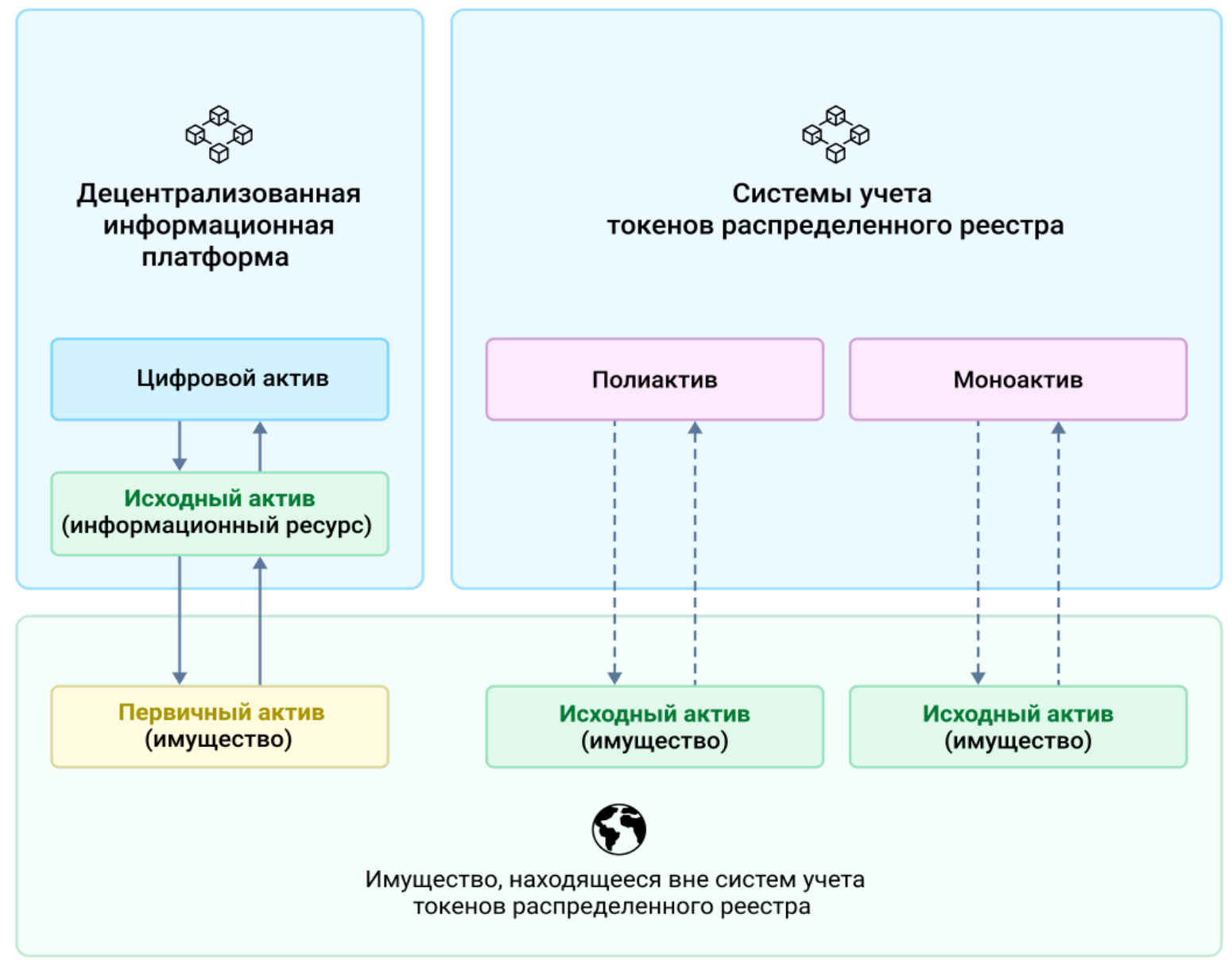

Принцип комплексности природы виртуальных активов в качестве принципа построения классификации виртуальных активов как инструментов для реализации способов финансового и управленческого учета имущества на основе рассмотрения технологической, экономико-правовой и информационно-прикладной природы можно проиллюстрировать с помощью графического отображения классификации виртуальных активов (Рисунок 8).

Как было отмечено ранее, в процессе рассмотрения экономико-правовой природы приоритет был отдан виртуальным активам распределенного реестра по причине сравнительно большой степени изученности виртуальных активов нераспределенного реестра, что не представляет интереса для их исследования с целью определения важных для установления корректного правового режима особенностей.

В рамках рассмотрения информационноприкладной природы приоритет был отдан изучению характеристик токенизированного актива в силу определения данного объекта в качестве перспективного направления с точки зрения его исследовательского потенциала и дальнейшего применения в экономике и праве.

Предложенная в рамках данного исследования классификация виртуальных активов как инструментов для реализации способов финансового и управленческого учета имущества 
является научно обоснованной, имеет основание классификации и может иметь практическое значение для установления корректного правового режима для каждого из указанных видов виртуальных активов.

Инструменты распределенного реестра, в частности такой наиболее перспективный вид виртуального актива распределенного реестра, как токенизированный актив, могут стать движущей силой модернизации мировой экономики. На наш взгляд, данная классификация может стать основой для разработки методики диагностики виртуального актива распределенного реестра на соответствие криптоактиву, моноактиву, полиактиву или цифровому активу как самому перспективному виду виртуального актива распределенного реестра, используемого в качестве инструмента для реализации способа финансового и управленческого учета имущества. Кроме того, дальнейшего изучения требует вопрос раскрытия природы информационного ресурса цифрового актива, изучение которого, в свою очередь, станет основой для научного обоснования модификации категории «единица учета цифрового актива» или «единицы цифрового актива», использование которой в рамках данного исследования носит обзорный характер.

\section{Рисунок 8}

Графическое отображение классификации виртуальных активов на основании комплексности их природы

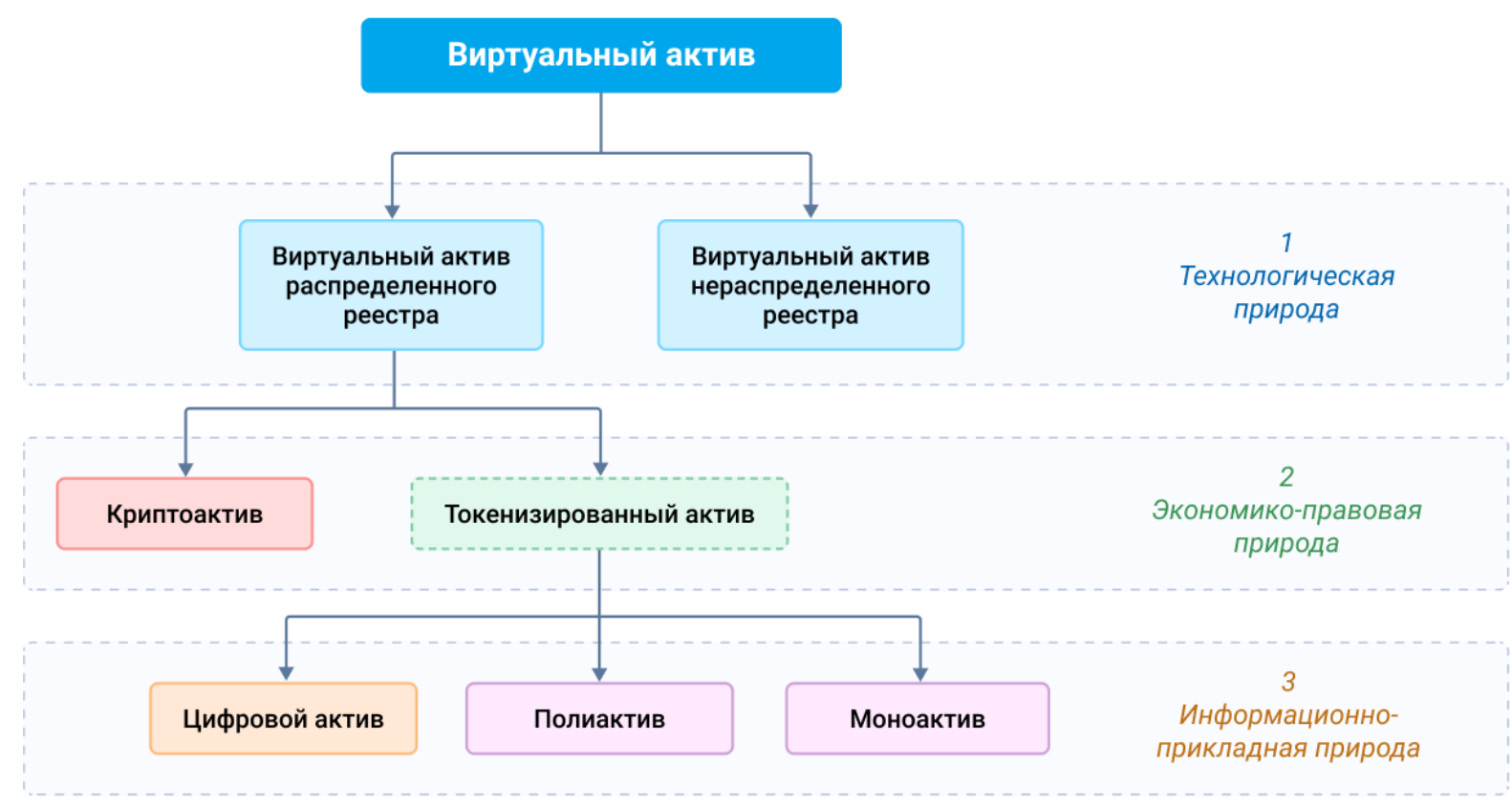

Создание комплексной классификации виртуальных активов как инструментов для реализации способов финансового и управленческого учета имущества позволило изучить субъектно-объектный состав отношений в сфере применения виртуальных активов. Данное исследование выполнило немаловажную роль в отношении дополнения в части способов ведения учета терминологического аппарата сферы применения виртуальных активов, предложенного для использования в работе «Феномен виртуальных активов: экономико-правовой аспект» (Kud, 2020a): 1. Виртуальный актив - цифровое выражение ценности, которым можно торговать в цифровом формате или которое можно переводить и использовать для платежных или инвестиционных целей (Financial Action Task Force, 2020).

2. Распределенный реестр - набор технических и программных устройств, работающих совместно, но децентрализованно и независимо друг от друга с целью регистрации событий с данными токена распределенного реестра посредством транзакций токена распределенного реестра, синхронизированных с помощью определенного алгоритма консенсуса. Технология распределенного реестра обеспечивает функционирование систем учета токенов распределенного реестра.

3. Виртуальный актив распределенного реестра вид виртуального актива, представленный в системе учета токенов распределенного реестра в виде определенного количества единиц учета токена распределенного реестра, которые в таких системах учета представлены в виде уникальных идентификаторов.

4. Виртуальный актив нераспределенного реестра - вид виртуального актива, созданный на базе иной технологии, отличной от технологии распределенного реестра.

5. Система учета токенов распределенного реестра - информационная система регистрации, хранения, обмена данными токенов распределенного реестра, которая основана на технологии распределенного реестра. 
6. Пользователь системь учета токенов распределенного реестра - физическое либо юридическое лицо, которое использует систему учета токенов распределенного реестра, в том числе, но не исключительно, с целью осуществления сделки с токенизированным активом и/или криптоактивом.

7. Идентификатор - атрибутивный признак объекта учета, служащий для его идентификации, который выражен в виде уникального набора буквенных и/или цифровых символов определенной длины и присваивается объекту учета в среде его обращения.

8. Хеш в системе учета токенов распределенного реестра - вид идентификатора, присваиваемый событиям в результате их регистрации в системе учета токенов распределенного реестра.

9. Умный контракт - электронный алгоритм, содержащий набор условий, которые исполняются в системе учета токенов распределенного реестра и полностью исключают человеческий фактор.

10. Токен распределенного реестра - объект системы учета токенов распределенного реестра, являющийся идентификатором структурированной определенным образом информации, которая может быть, но не исключительно, производной от исходного актива.

\section{1. Единица учета токена распределенного} реестра - объект учета данных токена распределенного реестра в системе учета токенов распределенного реестра.

12. Транзакция токена распределенного реестра процесс фиксации (запись в распределенном реестре в виде хеша транзакции) изменения адреса учета для определенного количества единиц учета токена распределенного реестра.

13. Хеш транзакции - вид идентификатора, присваиваемый транзакции токена распределенного реестра и формируемый на основе данных токена распределенного реестра.

14. Данные токена распределенного реестра совокупность атрибутов и свойств токена распределенного реестра: хеш токена распределенного реестра, хеши транзакций, количество единиц учета токена распределенного реестра и адрес хранения единиц учета такого токена распределенного реестра, а также других атрибутов и свойств, которые могут быть определены разработчиком (создателем) умного контракта такого токена распределенного реестра.

15. Токенизированный актив - вид виртуального актива, который существует в системе учета токенов распределенного реестра в виде записи с идентификатором информации, производной от исходного актива.

16. Исходный актив - имущество, право по распоряжению которым используется его собственником для создания токенизированного актива (Kud, 2020a).

17. Децентрализованная

информационная платформа - программно-аппаратный комплекс, инфраструктура которого состоит из компонентов и сервисов, включает систему учета токенов распределенного реестра и предоставляет своим пользователям возможность реализовывать имущественные и личные неимущественные отношения путем осуществления финансового и управленческого учета своих имущественных и личных неимущественных прав посредством цифровых активов.

18. Пользователь децентрализованной информационной платформы - физическое либо юридическое лицо, которое использует децентрализованную информационную платформу с целью реализации способов финансового и управленческого учета имущественных и личных неимущественных отношений посредством цифровых активов.

19. Поставщик услуг - пользователь децентрализованной информационной платформы, который предоставляет услуги в сфере токенизированных активов и криптоактивов, в том числе, но не исключительно, по обеспечению осуществления сделок с токенизированными активами и/или криптоактивами.

20. Потребитель услуг - пользователь децентрализованной информационной платформы, который получает услуги, доступные в децентрализованной информационной платформе, и/или использует токенизированные активы и/или криптоактивы, в том числе, но не исключительно, с целью осуществления хозяйственной деятельности или для личного пользования.

21.Цифровой актив децентрализованной информационной платформы токенизированного актива, единицы учета которого обладают свойством делимости или неделимости, количество которых соответствует определенному объему права на доступ к информационному ресурсу цифрового актива как его исходному активу, производному от первичного актива. Представляет собой договор (оферту), в соответствии с которым могут реализоваться взаимные обязательства должника (собственника исходного актива в виде информационного ресурса цифрового актива), а также множества должников (собственников первичных активов) и множества кредиторов (собственников единиц учета цифрового актива).

22. Первичный актив - имущество, существующее вне децентрализованной информационной платформы, право по распоряжению которым используется его собственником при формировании информационного ресурса цифрового актива как исходного актива для создания цифрового актива.

23. Информащионный ресурс цифррового актива исходный актив для цифрового актива в децентрализованной информационной платформе, представляющий собой результат интеллектуальной деятельности, который создается собственником первичного актива в объеме имеющихся у него прав на первичный актив. 
24. Полиактив системь учета токенов распределенного реестра - вид токенизированного актива, единицы учета которого обладают свойством делимости, количество которых соответствует определенному объему делимого имущественного права, производного от исходного актива. Представляет собой договор (оферту), в соответствии с которым могут реализоваться взаимные обязательства только одного должника (собственника исходного актива) и множества кредиторов (собственников единиц учета полиактива).

25. Моноактив системы учета токенов распределенного реестра - вид токенизированного актива, единицы учета которого обладают свойством неделимости, так как соответствуют неделимому объему прав на исходный актив. Представляет собой договор (оферту), в соответствии с которым могут реализоваться взаимные обязательства только одного должника (собственника исходного актива) и одного кредитора (собственника единиц учета моноактива).

26. Криптоактив - вид виртуального актива, который существует в системе учета токенов распределенного реестра в виде записи с идентификатором информации, непроизводной от исходного актива.

\section{Благодарности}

Автор статьи выражает искреннюю благодарность коллективу Научно-исследовательского центра экономико-правовых решений в сфере применения технологий распределенного реестра за весомый вклад в формирование концептуального видения классификации виртуальных активов, а именно за полезные консультации и конструктивные дискуссии, результаты которых легли в основу данной статьи. Особая благодарность выносится Дунаеву И. В., Мануйло С. Н., Журбе Ю. А., Резчик В. В., Басюку А. П.

\section{Источник финансирования}

Это исследование проводилось без гранта на базе Научно-исследовательского центра экономикоправовых решений в сфере применения технологий распределенного реестра в 2021 году в отношении вопроса регулирования виртуальных активов, использование преимуществ которых, по мнению FATF, возможно исключительно при наличии надлежащего правового регулирования (Financial Action Task Force, 2021), созданию которого способствует выявление видовых свойств виртуальных активов, позволяющих их классифицировать, а также определить сферы и субъектов регулирования отношений, возникающих в связи с применением тех или иных видов виртуальных активов.

\section{Конфликт интересов}

Автор заявляет об отсутствии конфликта интересов.

\section{Литература / References}

Alekseev, S. S. (2010). Sobranie sochinenij: T. 2. Spetsialnye voprosy pravovedeniya. [Collected works: Vol. 2. Special issues of jurisprudence]. Statut. [in Russian]

Bitbon System. (2020). Terms and definitions in the Bitbon System. https://www.bitbon.space/en/terms-anddefinitions/main-terms/bitbon-system

Borysova, V. I., Baranova, L. M., \& Biehova, T. I. (2011). Tsyvilne pravo [Civil law]. Pravo. [in Ukrainian]

Braddick, K., Bailey, A., \& Ramsden, D. (2018). Cryptoassets taskforce: final report. https://assets.publishing.service.gov.uk/govern ment/uploads/system/uploads/attachment_data/f ile/752070/cryptoassets_taskforce_final_report_ final_web.pdf

British Virgin Islands Financial Services Commission. (2020). Guidance on regulation of virtual assets in the Virgin Islands (BVI). https://www.bvifsc.vg/sites/default/files/guidanc e_on_regulation_of_virtual_assets_in_the_virgi n_islands_bvi_final.pdf

Chmylenko, F. O., \& Zhuk, L. P. (2014). Posibnyk do vyvchennia dystsypliny "Metodolohiia ta orhanizatsiia naukovykh doslidzhen" [Handbook for studying the discipline "Methodology and organization of scientific research"]. RVV DNU. http://kist.ntu.edu.ua/textPhD/mond.pdf [in Ukrainian]

Em, V.S. (2006). Grazhdanskoe pravo. T. 1. Obshchaya chast [Civil law. Vol. 1. General part]. Volters Kluver. [in Russian]

Eurasian Economic Commission. (2019). Kriptovaljuty $i$ blokchejn kak atributy novoj jekonomiki [Cryptocurrencies and blockchain as attributes of the new economy]. EEC. https://www.eurasiancommission.org [in Russian]

European Commission. (2020). Proposal for a regulation of the European Parliament and of the Council on markets in crypto-assets, and amending directive (EU) 2019/1937. https://eurlex.europa.eu/legalcontent/EN/TXT/?uri=CELEX\%3A52020PC0593

Financial Action Task Force. (2012). The FATF recommendations.

http://www.fatfgafi.org/publications/fatfrecommendations/docu ments/fatf-recommendations.html

Financial Action Task Force. (2020). Virtual assets red flag indicators of money laundering and terrorist financing. https://www.gfiu.gov.gi/uploads/8DovB_Virtual -Assets-Red-Flag-Indicators.pdf

Financial Action Task Force. (2021). Virtual assets: What, when, how? https://www.fatfgafi.org/media/fatf/documents/bulletin/FATFBooklet_VA.pdf

Financial Conduct Authority. (2019, January). Guidance on cryptoassets. 
https://www.fca.org.uk/publication/consultation/ cp19-03.pdf

Financial Monitoring Unit Government of Pakistan. (2020). Strategic analysis. Virtual assets emerging risk of money laundering and terrorism http://www.fmu.gov.pk/wpcontent/uploads/2020/05/Strategic-AnalysisReport-Sanitized-version.pdf

Hong Kong's Securities and Futures Commission. (2019, October 4). Hong Kong unveils licensing conditions for managers of virtual assets portfolios. Baker McKenzie. https://www.bakermckenzie.com/en/insight/publications/2019/10/hong-kong-virtual-assetsportfolios

International Financial Reporting Standards Foundation. (2020). List of IFRS standards and IFRIC Interpretations. https://www.ifrs.org/issued-standards/list-ofstandards/

Joyce, R. (2017). MSFO (IAS) 38 Nematerialnye aktivy [IFRS (IAS) 38 Intangible assets]. https://finotchet.ru/articles/1271/ [in Russian]

Kalambet, S. V., Ivanov, S. I., \& Pivnyak, Yu. V. (2015). Metodologiya naukovikh doslidzhen [Research methodology]. Makovetskii Publishing. https://pgasa.dp.ua/wpcontent/uploads/2017/10/3-1.pdf [in Ukrainian]

Kud, A. A. (2021). Detsentralizovani informatsiini platformy yak instrument modernizatsii publichnoho upravlinnia [Decentralized information platforms as a tool of public governance modernization]. Visnyk pisliadyplomnoi osvity - Bulletin of Postgraduate Education. Manuscript submitted for publication. [in Ukrainian]

Kud, A. A. (2020a). Fenomen virtualnykh aktivov: ekonomiko-pravovoj aspekt [The phenomenon of virtual assets: economic and legal aspects]. https://doi.org/10.26697/KRPOCH.Preprint.Kud .A.1.2020 [in Russian]

Kud, A. A. (2020b). Infrastructure asset of the Bitbon System - Simcord. Bitbon System https://www.bitbon.space/en/bitbon-protocol

Kud, A. A. (2019a). Metodika diagnostiki tokena blokcheina na sootvetstvie tsifrovomu aktivu [Methodology for determining whether a blockchain token corresponds to a digital asset].

KRPOCH. https://doi.org/10.26697/9786177089055.2019 [in Russian]

Kud, A., Kucheriavenko, N., \& Smychok, E. (2019). Tsifrovye aktivy $i$ ikh ekonomiko-pravovoe regulirovanie $v$ svete razvitiia tekhnologii blokchein [Digital assets and their economic and legal regulation in the light of the blockchain technology development]. Pravo. [in Russian]

Kud, A. (2019b). Substantiation of the term "digital asset": Economic and legal aspects. International Journal of Education and Science,
2(1),

https://doi.org/10.26697/ijes.2019.1.06

Kulikova, L. I.,

Vetoshkina, E. Yu., Akhmedzyanova, F. N., Ivanovskaya, A. V., \& Gubaidullina, A. R. (2014). Finansovyi uchet $i$ otchetnost [Financial accounting and accountability].

$\mathrm{K}(\mathrm{P}) \mathrm{FU}$. http://libweb.kpfu.ru/ebooks/72-

IEF/72_208_A5k1-000523.pdf [in Russian]

Kuznetsov, S. A. (1998). Bolshoi tolkovyi slovar russkogo yazyka [Great Explanatory Dictionary of the Russian Language]. Norint. [in Russian]

Lysenko, A. N. (2010). Imushchestvo v grazhdanskom prave Rossii [Property in civil law of Russia]. Delovoi dvor. [in Russian]

Ministry of Finance of the Russian Federation. (1999). Mezhdunarodnyi standart finansovoi otchetnosti (IAS) 38 "Nematerialnye aktivy" [International Financial Reporting Standard (IAS) 38 "Intangible assets". https://finotchet.ru/articles/155/ [in Russian]

Novikov, A. M., \& Novikov, D. A. (2010). Metodologiya nauchnogo issledovaniya [Research methodology]. Librokom. http://www.methodolog.ru/books/mni.pdf [in Russian]

Ozhegov, S. I., \& Shvedova, N. Yu. (2010). Tolkovyj slovar russkogo jazyka [Explanatory Dictionary of the Russian Language]. https://ozhegov.textologia.ru [in Russian]

Parliament of Malta. (2018, May 22). Act to regulate the field of initial virtual financial asset offerings and virtual financial assets. https://parlament.mt/media/94209/bill-44virtual-financial-assets-bill.pdf

Pypenko, I. S., \& Kud, A. A. (2019). Genesis of IT economy: from cryptocurrency to digital asset. International Journal of Education and Science, 2(2), 56. https://doi.org/10.26697/ijes.2019.2.41

Securities and Futures Commission. (2019, November 6). Regulation of virtual asset trading platforms. https://www.sfc.hk/web/files/ER/PDF/20191106\%20 Position\%20Paper\%20and\%20Appendix\%201\%20to $\% 20$ Position\%20Paper\%20(Eng).pdf

Stuarts Walker Hersant Humphries. (2020). Virtual assets - New Cayman Islands law proposed. https://www.stuartslaw.com/cms/document/Virtual_ Assets_New_Cayman_Islands_Law_Proposed.pdf

Swiss Financial Market Supervisory Authority. (2018, February 16). Guidelines for enquiries regarding the regulatory framework for initial coin offerings (ICOs). FINMA. https://www.finma.ch/en/news/2018/02/201802 16-mm-ico-wegleitung

Verkhovna Rada of Ukraine. (2020, August 16). Zakon Ukrainy "Pro zapobihannia ta protydiiu lehalizatsii (vidmyvanniu) dokhodiv, oderzhanykh zlochynnym shliakhom, finansuvanniu teroryzmu ta finansuvanniu rozpovsiudzhennia zbroi masovoho znyshchennia" [Law of Ukraine "On prevention and counteraction to legalization (laundering) 
of proceeds from crime, financing of terrorism and financing of proliferation of weapons of mass destruction"]. https://zakon.rada.gov.ua/laws/show/36120\#Text [in Ukrainian]

Vidyapin, V. I., Dobrynin, A. I., Zhuravleva, G. P., \& Tarasevich, L. S. (2003). Ekonomicheskaya teoriya [Economic theory]. INFRA-M. [in Russian]

Vitryanskii, V. V., $\quad$ Em, V. S., \& Kozlova, N. V. (2010). Rossiiskoe grazhdanskoe pravo: T. 2. Obyazatelstvennoe pravo [Russian civil law: Vol. 2. Obligatory law]. Statut. [in Russian]

World Federation of Exchanges. (2019). WFE response to the financial action task force - mitigating risks from virtual assets. https://www.worldexchanges.org/storage/app/media/wfe-responseto-the-financial-action-task-force-mitigatingrisks-from-virtual-assets.pdf

World Intellectual Property Organization. (2020). WIPO PROOF - Trusted digital evidence. https://www.wipo.int/wipoproof/en/index.html

Zakharkina, A. V. (2017). "Grazhdanskij oborot" kak fundamentalnaya tsivilisticheskaya kategoriya ["Civil circulation" as a fundamental category in civil law]. Vestnik Permskogo universiteta. Juridicheskie nauki - Perm University Herald. Juridical Sciences, 37, 323-333. https://doi.org/10.17072/1995-4190-2017-37323-333 [in Russian]

\begin{abstract}
Анотація
Вступ: Однією з проблем сучасних законодавців у різних країнах є те, щзо вони намагаються регулювати об'єкт, не розібравшись у природі його походження, щзо, логічно, тягне й безліч помилок щуодо його визначення в правовому полі. Відсутність уніфікованих визначень $і$ чіткої класифікації віртуальних активів як інструментів для реалізації способів фінансового й управлінського обліку майна за їх фундаментальними, характерними ознаками робить практично неможливим визначення важливих для правового регулювання характеристик віртуальних активів, а отже, $i$ їх закріплення в нормах права та встановлення належного правового режиму. Статтю присвячено вирішенню актуального та міждисциплінарного науково-прикладного завдання розроблення комплексної багаторівневої класифікачї віртуальних активів. На відміну від нечисленних наявних класифікацій, які сконщентровані на фрагментах феномену віртуального активу та вибіркових способах його застосування, у статті запропоновано всеосяжне бачення співвіднесення усіх відомих видів віртуальних активів, щзо дозволяє говорити про комплексність класифікації, поданої у цій статті.

Мета: Розробити та обтрунтувати комплексну багаторівневу класифікацію усіх відомих видів віртуальних активів, щуо дозволяе вирішити міждисциплінарне науково-прикладне завдання систематизації віртуальних активів для подальшого вироблення єдиного підходу до регулювання відносин, об'єктами яких виступають віртуальні активи різних видів.
\end{abstract}

Матеріали і Методи: Для дослідження природи віртуальних активів і розроблення комплексної класифікаџї було використано комплекс методів наукового дослідження: аналіз, зокрема аналіз причинно-наслідкових зв'язків, синтез, порівняльний метод, метод узагальнення, систематизації й інтерпретації результатів та індукція.

Результати: Окреслено триєдину природу віртуальних активів: технологічну, економіко-правову й інформачійно-прикладну. Ця класифікація віртуальних активів дозволить визначити перспективні інструменти для иілей обліку майна та прав. На відміну від інших відомих підходів до розрізнення віртуальних активів, у яких раніше необтрунтовану «першість» посідали криптоактиви (або криптовалюти), автор уперше виокремлює групу токенізованих активів. Саме ия група, завдяки наявності прямого зв 'язку з майном, дозволяє вести облік, а також здійснювати переоблік майна та прав у сучасних ичифрових системах обліку децентралізованих інформаційних платформах на базі технології розподіленого реєстру (блокчейн), тоді як за допомогою криптоактивів, через відсутність прямого зв'язку з майном, неможливо вести ией облік. Автор серед віртуальних активів виокремлює ицифровий актив й аналізує сутнісно-смислові особливості поняття «цифровий актив». В основу цифрового активу покладено унікальний інформаційний ресурс як первинний актив i властивість похідності від реального активу, щзо радикально відрізняє цчифровий актив від інших видів віртуальних активів. Усе ие дозволяє його розглядати як ефективний інструмент для реалізації способів фінансового й управлінського обліку майна. Отже, власники иифрового активу можуть здійснювати у новий спосіб облік своїх майнових і особистих немайнових прав. Грунтуючись на властивостях изирового активу, автор виокремлює інші види віртуальних активів: поліактив і моноактив, із відповідними прикладами. Наводить характеристику ӥх властивостей $i$ структурованих елементів, співвідносячи їх із характеристиками циифрового активу, а також пропонуючи чіткі та добре відомі фінансово-правові аналогї із реалізації взаємних зобов'язань між сторонами у традиційному правочині. У статті вперше запропоновано систематизацію семи властивостей і параметрів токенізованого активу та, як наслідок, опис властивостей трьох різновидів токенізованого активу: моноактиву, поліактиву та ичифрового активу. Це дозволило подати різновиди віртуальних активів у вигляді трирівневої класифікаиї, в основі якої знаходиться комплексність природи віртуальних активів. У авторській класифікації виокремлено сім різновидів віртуальних активів $i$ наведено їхню характеристику.

Висновки: Загалом запропонований підхід до класифікаиії дозволяє дати наукову відповідь на питання про те, на якій підставі співвіднести між собою безліч відомих видів віртуальних активів $і$ як віднести до них правовий режим держави. Ці розробки будуть корисні для законодавия практично будь-якої держави, 
державних органів фінансового, податкового та банківського контролю, а також для приватних компаній під час постановки на баланс та обліку віртуальних активів у своїй господарській діяльності.

Ключові слова: розподілений реєстр, блокчейн, віртуальний актив, токенізований актив, иифровий актив, поліактив, моноактив, криптоактив, децентралізована інформаційна платформа.

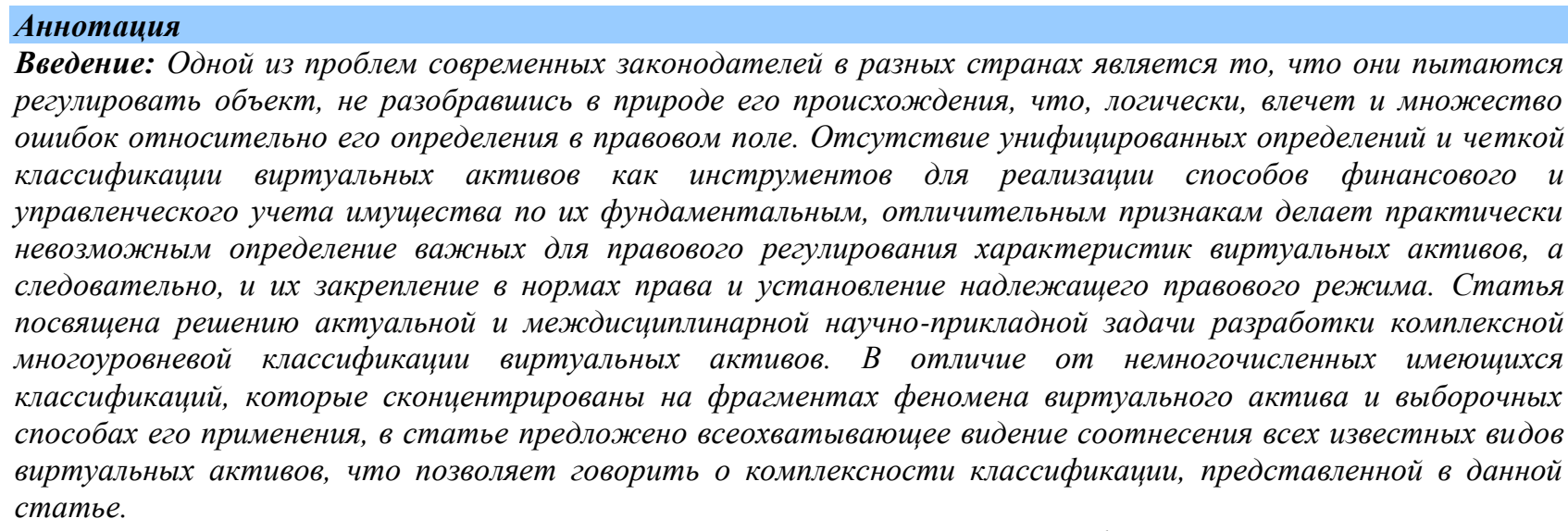

Цель: Разработать и обосновать комплексную многоуровневую классификацию всех известных видов виртуальных активов, что позволяет решить междисциплинарную научно-прикладную задачу систематизации виртуальных активов для дальнейшей выработки единого подхода к регулированию отнотений, объектами которых выступают виртуальные активы различных видов.

Материаль и Методы: Для исследования природы виртуальных активов и разработки комплексной классификации был использован комплекс методов научного исследования: анализ, в том числе анализ причинно-следственных связей, синтез, сравнительный метод, метод обобщения, систематизации и интерпретации результатов и индукияия.

Результаты: Обозначена триединая природа виртуальных активов: технологическая, экономико-правовая и информационно-прикладная. Данная классификация виртуальных активов определяет перспективные инструменты для целей учета имущества и прав. В отличие от иных известных подходов к различению виртуальных активов, в которых ранее необоснованное «первенство» занимали криптоактивы (или криптовалюты), автор впервые выделяет группу токенизированных активов. Именно данная группа, в силу наличия прямой связи с имуществом, позволяет вести учет, а также осуществлять переучет имущества и прав в современных ичифровых системах учета - децентрализованных информационных платформах на базе технологии распределенного реестра (блокчейн), тогда как посредством криптоактивов, в силу отсутствия прямой связи с имуществом, невозможно вести данный учет. Автор среди виртуальных активов выделяет цүифровой актив и анализирует сущностно-смысловые особенности понятия «цифровой актив». В основе ичифрового актива лежит уникальный информационный ресурс как исходный актив и свойство производности от реального актива, что радикально отличает цифровой актив от других видов виртуальных активов. Все это позволяет его рассматривать как эффективный инструмент для реализации способов финансового и управленческого учета имущества. Таким образом, собственники циифрового актива могут осуществлять учет новым способом своих имущественных и личных неимущзественных прав. Базируясь на свойствах цчифрового актива, автор выделяет иные виды виртуальных активов: полиактив и моноактив, с соответствующими примерами. Приводит характеристику их свойств и структурных элементов, соотнося их с характеристиками цифррового актива, а также предлагая четкие и хорошо известные финансовоправовые аналогии по реализации взаимных обязательств между сторонами в традиционной сделке. В статье впервые предложено систематизацию семи свойств и параметров токенизированного актива и, как следствие, описание свойств трех разновидностей токенизированного актива: моноактива, полиактива и ичифрового актива. Это позволило представить разновидности виртуальных активов в виде трехуровневой классификации, в основе которой лежит комплексность природы виртуальных активов. В авторской классификации выделень семь разновидностей виртуальных активов и дана их характеристика.

Выводы: В иелом предложенный подход к классификации позволяет дать научный ответ на вопрос о том, на каком основании соотнести между собой множество известных видов виртуальных активов и как отнести к ним правовой режим государства. Данные разработки будут полезны для законодателя практически любой страны, государственных органов финансового, налогового и банковского контроля, а также для частных компаний при постановке на баланс и учете виртуальных активов в своей хозяйственной деятельности.

Ключевые слова: распределенный реестр, блокчейн, виртуальный актив, токенизированный актив, ичифровой актив, полиактив, моноактив, криптоактив, децентрализованная информационная платформа.

The electronic version of this article and original article in English are the complete. It can be found online in the IJES Archive https://ijes.world/en/archive and in the KRPOCH Publishing Repository https://ekrpoch.culturehealth.org/handle/lib/58 